\title{
The circulation of Icelandic waters - a modelling study
}

\author{
K. Logemann ${ }^{1}$, J. Ólafsson ${ }^{1,2}$, Á. Snorrason ${ }^{3}$, H. Valdimarsson ${ }^{2}$, and G. Marteinsdóttir ${ }^{1}$ \\ ${ }^{1}$ School of Engineering and Natural Sciences - University of Iceland, Reykjavik, Iceland \\ ${ }^{2}$ Marine Research Institute Iceland, Reykjavik, Iceland \\ ${ }^{3}$ Icelandic Meteorological Office, Reykjavik, Iceland \\ Correspondence to: K. Logemann (kai@hi.is)
}

Received: 20 March 2013 - Published in Ocean Sci. Discuss.: 19 April 2013

Revised: 10 September 2013 - Accepted: 3 October 2013 - Published: 30 October 2013

\begin{abstract}
The three-dimensional flow, temperature and salinity fields of the North Atlantic, including the Arctic Ocean, covering the time period 1992 to 2006 are simulated with the numerical ocean model CODE. The simulation reveals several new insights and previously unknown structures which help us to clarify open questions on the regional oceanography of Icelandic waters. These relate to the structure and geographical distribution of the coastal current, the primary forcing of the North Icelandic Irminger Current (NIIC) and the path of the Atlantic Water south-east of Iceland. The model's adaptively refined computational mesh has a maximum resolution of $1 \mathrm{~km}$ horizontal and $2.5 \mathrm{~m}$ vertical in Icelandic waters. CTD profiles from this region and the river discharge of 46 Icelandic watersheds, computed by the hydrological model WaSiM, are assimilated into the simulation. The model realistically reproduces the established elements of the circulation around Iceland. However, analysis of the simulated mean flow field also provides further insights. It suggests a distinct freshwater-induced coastal current that only exists along the south-west and west coasts, which is accompanied by a counter-directed undercurrent. The simulated transport of Atlantic Water over the Icelandic shelf takes place in a symmetrical system of two currents, with the established NIIC over the north-western and northern shelf, and a hitherto unnamed current over the southern and southeastern shelf, which is simulated to be an upstream precursor of the Faroe Current (FC). Both currents are driven by barotropic pressure gradients induced by a sea level slope across the Greenland-Scotland Ridge. The recently discovered North Icelandic Jet (NIJ) also features in the model predictions and is found to be forced by the baroclinic pressure field of the Arctic Front, to originate east of the Kolbeinsey Ridge and to have a volume transport of around 1.5 Sv within
\end{abstract}

northern Denmark Strait. The simulated multi-annual mean Atlantic Water transport of the NIIC increased by $85 \%$ during 1992 to 2006, whereas the corresponding NIJ transport decreased by $27 \%$. Based on our model results we propose a new and further differentiated circulation scheme of Icelandic waters whose details may inspire future observational oceanography studies.

\section{Introduction}

The waters surrounding Iceland, flowing over the shelf and along the adjacent continental slope, form one of the hydrographically most complicated regions of the North Atlantic. The primary drivers of this complexity are topography and the interaction of four water masses. Iceland is located at the junction of the Mid-Atlantic Ridge and the GreenlandScotland Ridge, which segments the adjacent Atlantic into four basins bounded by the Reykjanes Ridge to the south, the Kolbeinsey Ridge to the north, the Greenland-Iceland Sill (Denmark Strait) to the west and the Iceland-Faroe Ridge to the east (Fig. 1).

The water mass of primary importance for the Icelandic hydrography is the Atlantic Water which has sub-tropical components and therefore is still comparatively warm (temperature $T$ between 6 and $11^{\circ} \mathrm{C}$ ) and salty (salinity $S$ between 35.0 and 35.2) when reaching Iceland (Stefánsson, 1962). East of the Reykjanes Ridge this water mass flows northwards as part of the broad and sluggish North Atlantic Drift; a north-eastward continuation of the Gulf Stream. Along the western flank of the Reykjanes Ridge, however, the flow is more energetic. Here, the Irminger Current (IC), another Gulf Stream continuation, carries Atlantic and 


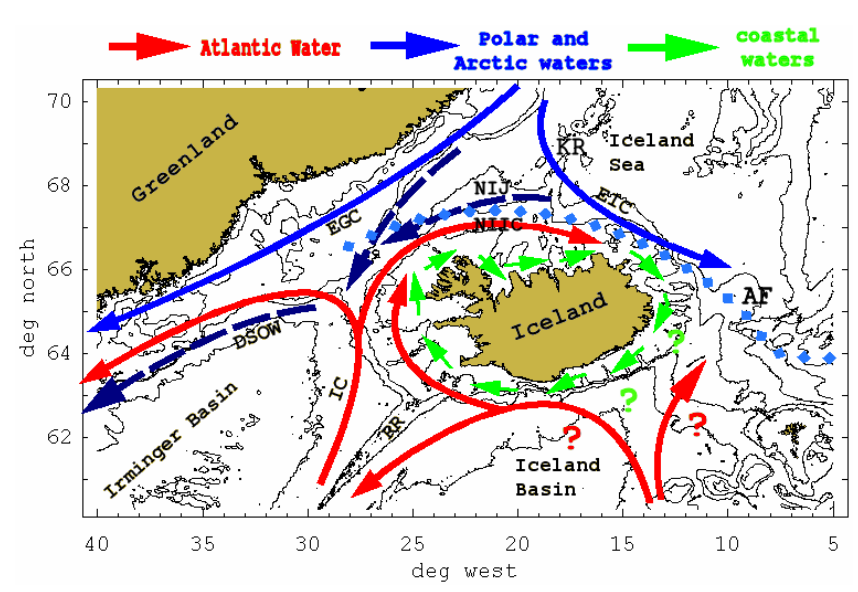

Fig. 1. Bathymetry around Iceland and the classical view of the ocean circulation. The isobaths are: 200, 500, 1000, 2000 and 3000 meters. The abbreviations are: AF - Arctic Front, DSOW - Denmark Strait Overflow Water, EGC - East Greenland Current, EIC - East Icelandic Current, IC - Irminger Current, KR - Kolbeinsey Ridge, NIIC - North Icelandic Irminger Current, NIJ - North Icelandic Jet, RR - Reykjanes Ridge. The question marks indicate questionable structures like the coastal current. Modified after Logemann and Harms (2006).

Subpolar Mode Water northwards. The IC volume flux was estimated at $19 \pm 3 \mathrm{~Sv}$ by Våge et al. (2011a). The associated northward heat flux plays a crucial role for the marine and terrestrial climate of Iceland. South of Denmark Strait, the IC mostly recirculates towards the west and further southwards along the East Greenland continental slope. However, a small fraction (5-10\%) of the current branches off northwards through Denmark Strait and further eastwards over the North Icelandic shelf (Kristmannsson, 1998). This branch, called the North Icelandic Irminger Current (NIIC), is responsible for the mild climate north of Iceland and forms, to a certain extent, the lifeline of the local marine ecosystem (Vilhjálmsson, 1997).

In normal years, the Atlantic Water of the NIIC, with some admixture of Polar Water entrained in Denmark Strait, dominates most of the North Icelandic shelf area. However, on its eastward journey over the northern shelf the admixture of the second water mass, the Arctic Intermediate Water, becomes more and more important. This water mass, often also termed Arctic waters, is formed of Atlantic Water which moved into the Nordic seas, mainly over the Faroe-Iceland Ridge and through the Faroe-Shetland Channel (Orvik et al., 2001), several years prior and has been exposed to atmospheric cooling and freshwater addition in the interior Greenland and Iceland seas since that time. It is therefore colder ( $T$ : -1 to $4^{\circ} \mathrm{C}$ ) and slightly fresher ( $S 34.6$ to 34.9 ) than the Atlantic Water (Swift, 1986). The East Icelandic Current (EIC) carries Arctic Intermediate Water, with an admixture of Polar Water, from the central Iceland Sea southwards along the eastern flank of the Kolbeinsey Ridge onto the north-eastern
Icelandic shelf, causing the water here to be characteristically more Arctic than Atlantic. Thereafter, the EIC, whose volume flux was measured to be $2.5 \mathrm{~Sv}$ between June 1997 and June 1998 (Jónsson, 2007), continues towards the northern flank of the Iceland-Faroe Ridge.

East of Iceland the Arctic waters of the EIC border on the Atlantic Water of the Faroe Current (FC) which flows eastwards along the northern flank of the Iceland-Faroe Ridge. The front between the cold Arctic waters to the north and the warm Atlantic Water of the NIIC and FC to the south is called Arctic Front and is characterised by sharp temperature gradients (Hansen and Meincke, 1979; Orvik et al., 2001). The resulting density gradient leads to differences in sea level height, with higher values to the warmer and less dense southern side of the front. The Arctic Front continues south-eastwards along the Iceland-Faroe Ridge, to the region north of the Faroe Islands. Westwards it extends north of Iceland up to Denmark Strait where it opens out into the Polar Front (Fig. 1). Below the NIIC there exists a deep undercurrent which carries Arctic waters westwards along the north Icelandic continental slope from east of the Kolbeinsey Ridge up to Denmark Strait. This current, discovered only in 2004 (Jónsson and Valdimarsson, 2004), is called the North Icelandic Jet (NIJ) and seems to make a crucial contribution to the Denmark Strait Overflow, a key element of the Atlantic meridional overturning circulation (Våge et al., 2011b).

The third water mass is Polar Water that originates in the surface layer of the Arctic Ocean. Here, the freshwater discharge of the great Siberian and Canadian rivers forms very fresh $(S<34.4)$ and, due to atmospheric cooling, very cold $\left(T<0{ }^{\circ} \mathrm{C}\right)$ surface water. A part of this water mass leaves the Arctic Ocean with the East Greenland Current (EGC) which flows southwards over the East Greenland shelf, thereby forming the Polar Front at the interface to the adjacent Arctic and Atlantic water masses (Swift, 1986). Hence, the bulk of the Polar Water, which is mostly ice covered, passes Iceland along the western side of the Denmark Strait whereas smaller parts mix into the NIIC to the east (Logemann and Harms, 2006; Jónsson and Valdimarsson, 2012). This seems to happen mainly in the form of cold and fresh eddies separating from the Polar Front (Våge et al., 2013). Furthermore, the variable wind field north of Denmark Strait may cause events of eastward drift of Polar Water onto the North Icelandic shelf. The Polar Water was in fact observed to dominate the North Icelandic shelf during the period between 1965 and 1971 (Malmberg and Kristmannsson, 1992).

During other cooling events, a strong northerly wind north of Denmark Strait (Logemann and Harms, 2006) caused an NIIC collapse without a marked westward drift of Polar Water, leading instead to the predominance of Arctic waters over the northern shelf. Thus, Malmberg and Kristmannsson (1992) concluded that three different marine climates alternately reign over the North Icelandic shelf: the Polar, the Arctic and the Atlantic climate. It has been the latter that 
has prevailed since 1996, with a trend of increasing stability (Jónsson and Valdimarsson, 2012).

The fourth and final water mass is coastal water. The freshwater discharge along the Icelandic coast produces lowsalinity near-shore water which is enriched by the riverborne silicate (Ólafsson et al., 2008). The classical view of the circulation pattern is that the coastal water flows clockwise around the island (Fig. 1). A discrete coastal current, driven by the barotopic pressure field related to a freshwater induced coastal density front, has been observed several times (Ólafsson, 1985; Ólafsson et al., 2008) and numerous satellite images (e.g., at the NASA MODIS project gallery, http://modis.gsfc.nasa.gov/) show the appearance of a distinct coastal water mass, visible through a combination of algal bloom and riverine suspended matter. However, the temporal variability and geographical distribution of this water mass and its accompanying ocean current, the Icelandic Coastal Current (ICC), is still unclear. Further, even the concept of the continuous circular clockwise flow seems to contradict drift observations at the south-east coast of Iceland (Valdimarsson and Malmberg, 1999).

The importance of the coastal water and its flow for the marine ecosystem is beyond dispute. The nutrients it contains, along with the stratifying effect of the freshwater on the water column, are thought to be important elements of the spring algal bloom in Icelandic waters (Pórðardóttir, 1986). Furthermore, the flow acts as a dispersal vector for fish eggs and larvae transported away from spawning grounds to their nursery areas, and hence plays a crucial role in the recruitment process of several fish species in Icelandic waters (Ólafsson, 1985; Marteinsdóttir and Astpórsson, 2005).

The uncertainty over the structure of the ICC is a key motivation for the present study. We also explore the general forcing of the NIIC, a current flowing northwards against the prevailing wind direction (Fig. 14) and a subject of intensive research for more than $50 \mathrm{yr}$ due to its exceptional hydrographical and ecological importance for North Icelandic waters (e.g., Stefánsson, 1962; Kristmannsson, 1998; Ólafsson 1999, Jónsson and Valdimarsson 2005, 2012, Halldórsdóttir, 2006; Logemann and Harms 2006). Furthermore, we examine the structure of the relatively unexplored NIJ and the path of the Atlantic Water flow towards the south and south-east coast of Iceland, a controversial component of the regional hydrography (e.g., Valdimarsson and Malmberg, 1999; Orvik and Niiler, 2002; Hansen et al., 2003).

To address these objectives we need to explore and understand the three-dimensional flow, temperature and salinity fields of the waters surrounding Iceland and beyond. We use the tool of numerical ocean modelling, which offers the possibility to obtain the requested fields with high temporal and spatial resolution covering large areas and long time periods.

The most established numerical model of Icelandic waters is a two-dimensional application of the POM ocean model (Blumberg and Mellor, 1978). It was set up for Icelandic waters by Tómasson and Eliasson (1995) and further improved by Tómasson and Káradóttir (2005). The model is run on an operational basis at the Icelandic Maritime Administration to predict tidal and atmospherically forced sea level elevations and currents.

The first three-dimensional model study on Icelandic waters was performed by Mortensen (2004). By using an application of the MIKE3 (Rasmussen, 1991) ocean model with a resolution of $20 \mathrm{~km}$ horizontal and $50 \mathrm{~m}$ vertical his study mainly dealt with the circulation in Denmark Strait, with volume, heat and salt fluxes of the EGC and the Denmark Strait Overflow.

In 2006 three further modelling studies on Icelandic waters were published. Ólason (2006) set up the MOM4 ocean model (Griffies et al., 2004) for the region with a resolution of around $15 \mathrm{~km}$ horizontal and $10 \mathrm{~m}$ vertical near the sea surface. Driven by climatological wind fields the model successfully reproduced the basic elements of the circulation. Sensitivity experiments regarding the role of the local wind stress in forcing the near surface circulation were carried out. Halldórsdóttir (2006) applied the same model whereas her numerical experiments examined the dynamic impact of the coastal freshwater and the sensitivity of the NIIC to wind stress variations. Eventually, Logemann and Harms (2006) published their work on the high-resolution $(1 \mathrm{~km}$ horizontal, $10 \mathrm{~m}$ vertical) simulation of the NIIC with the ocean model CODE. Time and space variability of the NIIC volume and heat fluxes for the years 1997-2003 were analysed and the origin and composition of NIIC water masses were estimated.

For the following years the development work on the CODE model with focus on Icelandic waters was carried on (Logemann et al., 2010, 2012) which finally led to the version whose output is presented here. This resolves the entire coastal area with a grid spacing of $1 \mathrm{~km}$ horizontal and $2.5 \mathrm{~m}$ vertical. It uses coastal freshwater discharge values computed by a newly developed high-resolution application of the hydrological model WaSiM (Schulla and Jasper, 2007; Einarsson and Jónsson, 2010) and it assimilates hydrographic measurements like CTD (conductivity, temperature, depth) profiles into the simulation.

Therefore, we propose that these model results could throw new light on the above-mentioned questions and even enable us to propose previously unobserved structures of the regional hydrography of Icelandic waters.

\section{Model description}

The numerical ocean model used for this study is CODE (Cartesian coordinates Ocean model with three-Dimensional adaptive mesh refinement and primitive Equations). A detailed description of the current model version (9.221) with all physical equations, algorithms and numerical techniques is given in Logemann et al. (2012). Here, we present the fundamentals of the model and outline recent improvements. 
The basis of the model is formed by the primitive equations (Bjerknes, 1921), i.e. non-linear, incompressible, formulations of the Navier-Stokes equations, which are used to approximate the oceanic flow in Cartesian coordinates $(x, y, z)$ in a hydrostatic pressure field. In order to simulate tides the tidal potential, given by a first order approach (Apel, 1987), was added. Here, we set the solar and lunar co-declinations to time invariant constants which reduces the tidal spectrum mainly to the $\mathrm{M}_{2}$ and $\mathrm{S}_{2}$ constituents (Logemann et al., 2012). The density of seawater as a function of salinity $S$, temperature $T$ and hydrostatic pressure is computed with the EOS-80 equations by Millero et al. (1980).

Temperature and salinity changes are computed with (e.g., Pedlosky, 1987)

$$
\begin{aligned}
\frac{\partial T}{\partial t} & =-u \frac{\partial T}{\partial x}-v \frac{\partial T}{\partial y}-w\left(\frac{\partial T}{\partial z}+\Gamma\right)+\frac{\partial}{\partial x}\left(K_{\mathrm{H}, T} \frac{\partial T}{\partial x}\right) \\
& +\frac{\partial}{\partial y}\left(K_{\mathrm{H}, T} \frac{\partial T}{\partial y}\right)+\frac{\partial}{\partial z}\left(K_{\mathrm{V}, T}\left(\frac{\partial T}{\partial z}+\Gamma\right)\right)+Q_{T}, \\
\frac{\partial S}{\partial t} & =-u \frac{\partial S}{\partial x}-v \frac{\partial S}{\partial y}-w \frac{\partial S}{\partial z}+\frac{\partial}{\partial x}\left(K_{\mathrm{H}, S} \frac{\partial S}{\partial x}\right) \\
& +\frac{\partial}{\partial y}\left(K_{\mathrm{H}, S} \frac{\partial S}{\partial y}\right)+\frac{\partial}{\partial z}\left(K_{\mathrm{V}, S} \frac{\partial S}{\partial z}\right)+Q_{S},
\end{aligned}
$$

in which $(u, v, w)$ is the three-dimensional flow vector and $\Gamma=\Gamma(T, S, p)$ is the adiabatic lapse rate, computed with the equation of Fofonoff and Millard (1983), whereas $Q_{T}$ and $Q_{S}$ denote the sum of surface heat and freshwater fluxes, respectively. These fluxes are derived by the atmospheric forcing (wind, air temperature, humidity, cloudiness) using the bulk formulas after Gill (1982). The coefficients of horizontal turbulent exchange, $K_{\mathrm{H}, T}$ and $K_{\mathrm{H}, \mathrm{S}}$, are estimated using the approach of Smagorinsky (1963), the coefficients of vertical turbulent exchange, $K_{\mathrm{V}, T}$ and $K_{\mathrm{V}, S}$, are computed after Pohlmann (1996) based on the approach of Kochergin (1987).

The current CODE version uses a dynamic thermodynamic sea ice model based on the work of Hibler (1979). Whereas the thermodynamic part (ice growth and melting) is coupled to the oceanic surface heat flux $Q_{T}$ in Eq. (1) the dynamic part contains a viscous-plastic rheology in order to compute the ice drift and rafting forced by the wind, the ocean currents and the sea surface elevation gradient (Logemann et al., 2010).

\subsection{Numerics}

The model equations are numerically solved with the technique of finite differences in Cartesian coordinates. A three-dimensional staggered Arakawa-C-grid (Mesinger and Arakawa, 1976) with a spatially variable resolution is constructed. The equations' numerical equivalents are formulated centred in space and mostly implicit in time. In order to avoid numerical diffusion of the advection terms a flux limiter function (van Leer, 1979) is used, which ensures the abidance of the total variation diminishing (TVD) condition.

\subsubsection{Adaptive mesh refinement and model domain}

CODE uses a technique of adaptive mesh refinement which is oriented at the "tree-algorithm" of Khokhlov (1998). This algorithm starts with a model domain being divided by a regular three-dimensional computational mesh of basic cells. If there is an area which demands a higher resolution, each basic cell of this area is split into eight "children" with halved side lengths. Some of these children may be split further, each of them into eight "grandchildren", those perhaps into "great-grandchildren" and so on, until the area of interest is resolved with the desired resolution. The model equations are only solved for "childless" cells, but the "parent" cells are not removed from the computer memory. At each time step, they obtain the average properties of their children instead. These values may be used for numerical operations at coarser parts of the mesh.

The actual form of adaptive mesh refinement is static, i.e., it does not vary in time, and just follows geographical criteria. By using five different stereographic projections, with their projection points along the $40^{\circ} \mathrm{W}$ meridian and weighted by a latitude dependent function, a Cartesian coordinates model domain containing the entire North Atlantic including the Arctic Ocean was constructed (Fig. 2). This domain is resolved by a basic mesh with a spacing of $128 \mathrm{~km}$ horizontal and $160 \mathrm{~m}$ vertical. First the cell thickness is refined up to $2.5 \mathrm{~m}$ close to the sea surface then the horizontal and deeper vertical mesh structure is further refined in selected regions. The refinement begins in the Nordic Seas, the Irminger and Iceland Basin, the Canadian Archipelago and along the northern Mid-Atlantic Ridge, continues with further refinement along the Greenland-Iceland-Scotland Ridge and finally leads to a mesh with $1 \mathrm{~km}$ horizontal and 2.5 to $10 \mathrm{~m}$ vertical resolution along the Icelandic coast (Fig. 2).

\subsubsection{Data assimilation}

The simulated temperatures and salinities at a certain distance from Iceland, i.e. the area south of $60^{\circ} \mathrm{N}$, north of $70^{\circ} \mathrm{N}$, west of $30^{\circ} \mathrm{W}$ and east of $5^{\circ} \mathrm{W}$, are restored to the climatologic fields of the PHC 3.0 (Polar Science Center Hydrographic Climatology) data set (Steele et al., 2001). This data set, compiled in 2005, combines the "Word Ocean Atlas" (1998 edition), the "Arctic Ocean Atlas" and selected Canadian data provided form the Bedford Institute of Oceanography and therefore forms an appropriate resource for the simulation of the North Atlantic/Arctic Ocean (Li et al., 2011). The restoring consists of a 365-day Newtonian scheme towards the 12 monthly fields of the PHC.

However, within the highly resolved area around Iceland, this restoring to climatological means, which would have led to an underestimated temporal and spatial variability, was discarded. Instead, we used the NISE (Nilsen et al., 2006) data set (with some additional information from the VEINS 

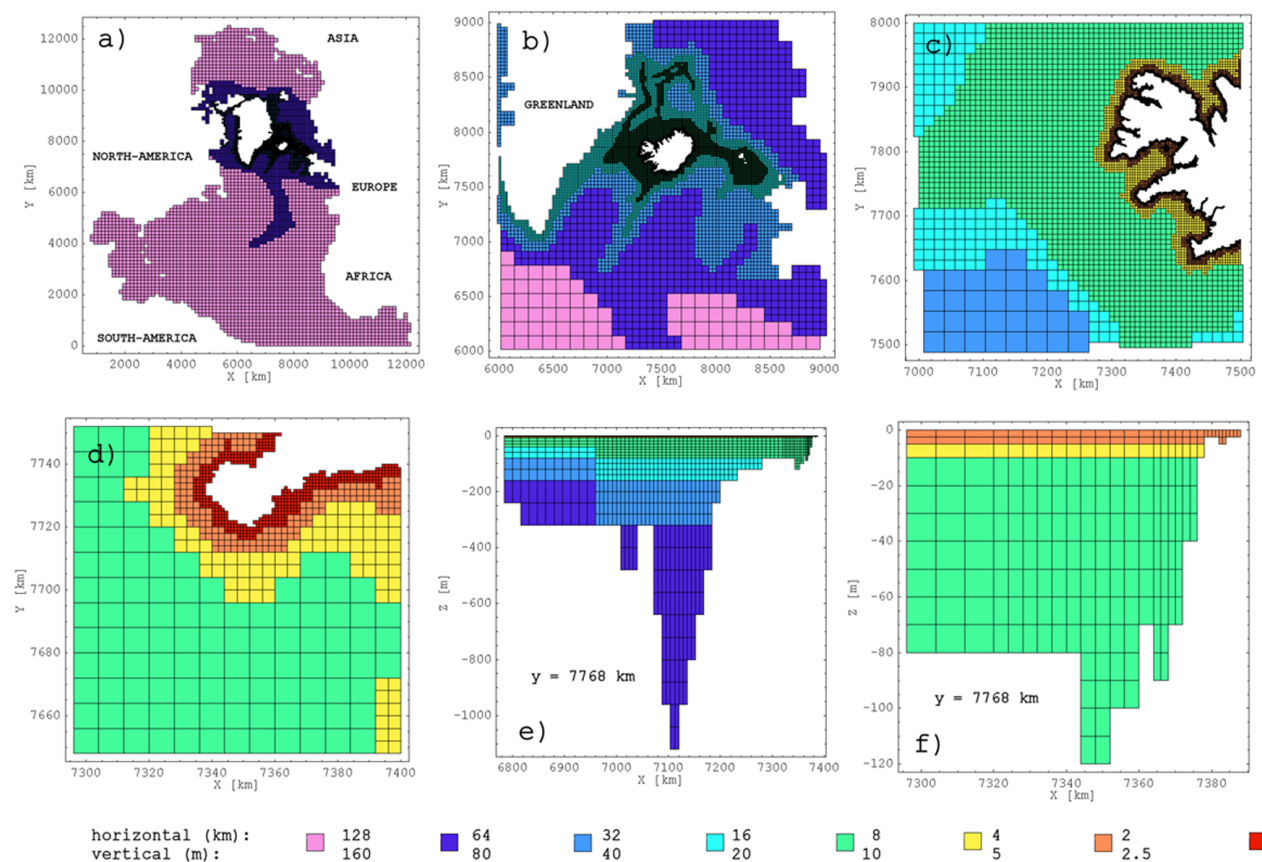

vertical (m)
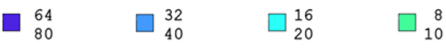

$\square_{5}^{4} \quad \square_{2.5}^{2}$

Fig. 2. The computational mesh in Cartesian coordinates. Different colours are used to identify the different resolutions. (a) The entire model domain. (b-d) The horizontal refinement. (e-f) The vertical refinement along a section west of Iceland.

data set (ICES, 2000)) and extracted 16,802 CTD (conductivity, temperature, depth) profiles from the period 1992 to 2006 recorded between $60^{\circ} \mathrm{N}$ and $70^{\circ} \mathrm{N}$ and between $30^{\circ} \mathrm{W}$ and $5^{\circ} \mathrm{W}$. This meant that 93 profiles per simulated month were available on average with May and June being the bestsurveyed months with on average 206 and 143 profiles, respectively whereas December and January show the lowest numbers, 30 and 23, respectively. With the help of $T / S$ and latitude/longitude diagrams the quality of the input data and its processing into the model was checked. No spikes or other great errors were detected which is not surprising considering the fact that, before delivery to the data base, a standard high level quality control was performed by each data contributor and an additional data cleaning has been applied to the data sets afterwards (ICES, 2000; Nilsen et al., 2006).

In order to adjust the model towards these observations we used the data assimilation technique of IAU (incremental analysis updating) processes (Bloom et al., 1996). Though more sophisticated methods like the "Practical Global State Estimation" (Wunsch and Heimbach, 2007) may have led to better results we decided to start the related model development with the implementation of a rather simple, straightforward and computationally less intensive algorithm. The model performing a "free forecast" simulation was stopped when having reached the 15th of a month. The CTD data of this month, i.e. from the 1 to the 30, was bundled and compared with the simulated fields. Based on the assumption that the differences between the simulation and the calibrated high quality CTD profiles are close to the true model error, the profiles of temperature and salinity difference were horizontally interpolated, in order to create estimates of the three-dimensional temperature and salinity error fields. The model was jumped one month back in time and the simulation re-started, but now with the correction terms $\Delta u, \Delta v, \Delta w, \Delta K_{\mathrm{H}, T}, \Delta K_{\mathrm{H}, \mathrm{S}}, \Delta K_{\mathrm{V}, T}, \Delta K_{\mathrm{V}, S}, \Delta Q_{T}, \Delta Q_{S}$ determined for every grid cell at every time step in order to correct the flow field, mixing rates or surface fluxes. These terms essentially are functions of the horizontally interpolated error field and the simulated difference from the free forecast. A detailed description of their computation is given in Logemann et al. (2012).

This way, Eq. (1) becomes

$$
\begin{aligned}
& \frac{\partial T}{\partial t}=-(u+\Delta u) \frac{\partial T}{\partial x}-(v+\Delta v) \frac{\partial T}{\partial y}-(w+\Delta w)\left(\frac{\partial T}{\partial z}+\Gamma\right) \\
& +\frac{\partial}{\partial x}\left(\left(K_{\mathrm{H}}, T+\Delta K_{\mathrm{H}, T}\right) \frac{\partial T}{\partial x}\right)+\frac{\partial}{\partial y}\left(\left(K_{\mathrm{H}, T}+\Delta K_{\mathrm{H}, T}\right) \frac{\partial T}{\partial y}\right) \\
& +\frac{\partial}{\partial z}\left(\left(K_{\mathrm{V}, T}+\Delta K_{\mathrm{V}, T}\right)\left(\frac{\partial T}{\partial z}+\Gamma\right)\right)+Q_{T}+\Delta Q_{T}+\Delta Q_{T}^{\mathrm{NUM}}
\end{aligned}
$$

whereas the correction terms are zero, with the exception of the one related to the term of the greatest absolute value, assumed to be the cause of the error. Salinity (Eq. 2) is treated analogously. Once the 15th of the month is reached again, new error fields are computed and the corresponding correction terms are added to the previous terms before the model jumps back in time again and repeats the simulation. The current model version uses three of these iterations. Thereby the mean temperature (salinity) deviation between model 

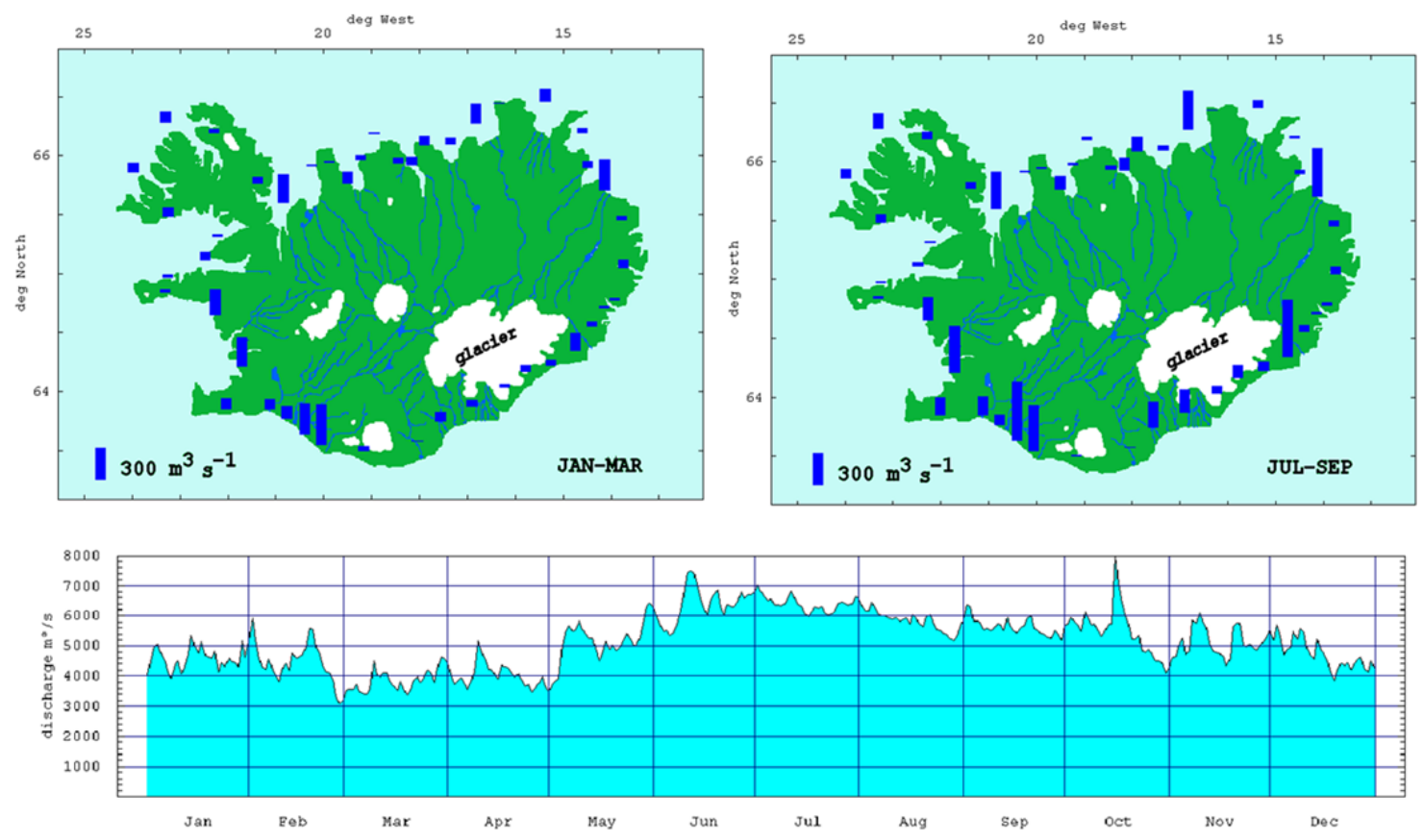

Fig. 3. Winter (left panel) and summer (right panel) mean discharge of 46 Icelandic watersheds for the time period 1992 to 2006 simulated with WaSiM. Below the simulated mean seasonal signal of the island's overall discharge for the same time period is shown.

and CTD data is reduced from initial $-0.989 \mathrm{~K}(0.176)$ to $-0.233 \mathrm{~K}(0.038)$ after the third iteration. The correction term $\Delta Q^{\mathrm{NUM}}$ denotes additional corrections of the simulated temperature or salinity, being activated during the last two iterations, having the function of "un-physically" correct numerical errors like numerical diffusion or erroneous initial or boundary conditions.

\section{Simulation of the period 1992-2006}

\subsection{Setup}

The two oceanic boundaries of the model domain - slightly south of the equator between South America and West Africa and across Bering Strait in the Arctic - are treated as closed boundaries. Because of the far field restoring towards climatological values, the hydrodynamic implications of these boundary conditions are assumed to be negligible for Icelandic waters. Initial model data, describing the summer 1991, were taken from a model run performed by a previous model version (Logemann et al., 2010).

The atmospheric forcing of the model consists of the 6hourly NCEP/NCAR re-analysis fields (Kalnay et al., 1996). This state-of-the-art data set (Hodges at al., 2011; Mooney et al., 2011; Tilinia et al., 2013) was chosen because it stretches back to the year 1948 and therefore allows a greater flexibility in the setup of future hindcast simulations. The model reads in the following seven parameters: precipitation rate, specific humidity $(2 \mathrm{~m})$, sea level pressure, air temperature
$(2 \mathrm{~m})$, total cloud cover, zonal and meridional wind speed $(10 \mathrm{~m})$.

During the simulation, three-hourly means of the physical ocean state, including sea ice properties, were stored. The averaging period of three hours was chosen to resolve tidal dynamics.

\section{Icelandic river runoff}

In order to simulate the hydrodynamic impact of river runoff along the Icelandic coast, the output of the hydrological model WaSiM, operated by the Icelandic Meteorological Office, was used (Schulla and Jasper, 2007; Einarsson and Jónsson, 2010). The model's meteorological input data, i.e., precipitation, evaporation and air temperature fields, was provided by the PSU/NCAR MM5 numerical weather model (Grell et al., 1994) driven by initial and boundary data from the European Centre for Medium-range Weather Forecasts (ECMWF). The simulated precipitation and the resulting river discharge values given by WaSiM compared favourably with hydrological records (Rögnvaldsson et al., 2007).

Hence, the hydrological input data for our ocean model consisted of the daily coastal freshwater discharge of 46 watersheds (Fig. 3). The discharge is implemented by prescribing the according rise of the sea surface and decrease of salinity for the model cell being closest to the river mouth. The resulting gain of mass of the entire model system is balanced by a sea surface elevation correction term being evenly spread over the entire model domain. The available WaSiM 
Table 1. Model temperature and salinity errors within Icelandic waters during the period 1992-2006 at the location and time of all available CTD profiles. Listed are the mean and the median model errors as well as the standard deviation $\sigma$ of the mean error.

\begin{tabular}{rrrrrrrr}
\hline $\begin{array}{r}\text { Depth } \\
\text { range }[\mathrm{m}]\end{array}$ & $\begin{array}{r}\text { Number } \\
\text { of obs. }\end{array}$ & $\begin{array}{r}\Delta T_{\text {mean }}[\mathrm{K}] \\
0-10\end{array}$ & $\begin{array}{r}\Delta T_{\text {median }} \\
{[\mathrm{K}]}\end{array}$ & $\begin{array}{r}\sigma_{T} \\
{[\mathrm{~K}]}\end{array}$ & $\Delta S_{\text {mean }}$ & $\Delta S_{\text {median }}$ & $\sigma_{S}$ \\
\hline $10-20$ & 28879 & 0.28 & 0.09 & 1.27 & 0.120 & 0.004 & 0.562 \\
$20-30$ & 28103 & -0.07 & -0.10 & 1.21 & 0.097 & 0.007 & 0.434 \\
$30-50$ & 54647 & -0.27 & -0.24 & 1.22 & 0.080 & 0.008 & 0.478 \\
$50-100$ & 119459 & -0.24 & -0.23 & 1.08 & 0.037 & 0.001 & 0.335 \\
$100-150$ & 59874 & -0.28 & -0.23 & 1.11 & 0.011 & -0.006 & 0.317 \\
$150-200$ & 51926 & -0.31 & -0.25 & 1.21 & 0.004 & -0.008 & 0.327 \\
$200-300$ & 80490 & -0.39 & -0.29 & 1.31 & -0.007 & -0.011 & 0.393 \\
\hline
\end{tabular}

data covered the period 1992-2006 and thus provided the temporal range of the ocean simulation.

Figure 3 shows the seasonal variation of the discharge and its spatial variation. Along the west coast, several watersheds show higher mean winter values compared with summer values due to higher precipitation in the winter months. However, most watersheds, and especially those being fed by glacier melt, e.g., at the south-east coast, show maximum values during late spring or summer.

\subsection{Results and validation}

In general, the model confirms the classic image of the circulation discussed above. The three-dimensional hydrography of Icelandic waters from 1992 to 2006 is well reproduced, including temporal anomalies, like the collapse of the NIIC during spring 1995 or its maximum in July 2003 (Jónsson and Valdimarsson, 2005). In order to monitor the model's ability to simulate temporal variability we have compared the freely forecasted monthly temperature and salinity change in Icelandic waters with the monthly change computed including the data assimilation routine. Hence, the portion of freely forecast change should be close to $0 \%$ if the model, just interpolating CTD profiles, were unable to reproduce any physical process. However, the median portions are $91 \%$ for temperature and $89 \%$ for salinity.

In accordance with observations (Jónsson and Valdimarsson, 2004; Våge et al., 2011b) the model shows the NIJ as a deep undercurrent along the North Icelandic continental slope dominating the deep southward transport in northern Denmark Strait. The simulated NIIC volume flux is realistic, but it has been under-estimated by previous model versions, which led to several model experiments incorporating a manipulated wind field over Denmark Strait (Logemann et al., 2010). However, not wind stress changes but the assimilation of CTD profiles finally caused the decisive jump of the simulated NIIC volume flux. This was surprising considering our numerical experiments that investigated the role of local density gradients in Denmark
Strait in forcing the NIIC did not show clear results (see Sect. 4).

The simulated temperature and salinity fields of Icelandic waters are close to observations (Fig. 4), which is not surprising considering the assimilation of CTD data. However, there are still deviations between the measured and the modelled data which are primarily caused by the sparse temporal resolution of the data assimilation routine, which was called only once per simulated month, i.e., the simulated fields describing the 15 th of each month were corrected towards estimations based on all measurements made during this month. The model errors at the time and location of the CTD profiles are given in Table 1.

The simulated ocean currents are also in general agreement with observations. We compared the modelled flow field at the depth of $15 \mathrm{~m}$ with observations from a series of surface drifter experiments performed by Valdimarsson and Malmberg (1999). These include 19 GPS tracks of drift at the depth of around $15 \mathrm{~m}$ in Icelandic waters between May 1998 and December 1999. By using a low-pass filter to remove tidal and shorter periods, i.e., by computing the mean drift over time intervals of $60 \mathrm{~h}, 607$ drift vectors were derived. These vectors were compared with their modelled counterparts (Fig. 5).

This comparison of the flow velocity resulted in a median (mean) model error of $-0.64 \mathrm{~cm} \mathrm{~s}^{-1}\left(-1.22 \mathrm{~cm} \mathrm{~s}^{-1}\right)$ with a standard deviation of $6.54 \mathrm{~cm} \mathrm{~s}^{-1}$, whereas the median (mean) error of the modelled flow direction was $4^{\circ}\left(6^{\circ}\right)$ to the right with a standard deviation of $67^{\circ}$. A former model version without CTD assimilation showed a median velocity error of $-2.8 \mathrm{~cm} \mathrm{~s}^{-1}$ (Logemann et al., 2010) which points to the improvement of the flow field simulation caused by the assimilation of CTD profiles.

We have compared the simulated $\mathrm{FC}$ across the $6^{\circ} \mathrm{W}$ meridian north of the Faroe Islands (dotted line in Fig. 5) with the observational records given by Hansen et al. (2010). The simulated FC volume flux during the time period 1998 to 2005 is $2.1 \mathrm{~Sv}$ whereas Hansen et al. (2010) state $3.5 \mathrm{~Sv}$ for the same time period. They also state the temperature and 

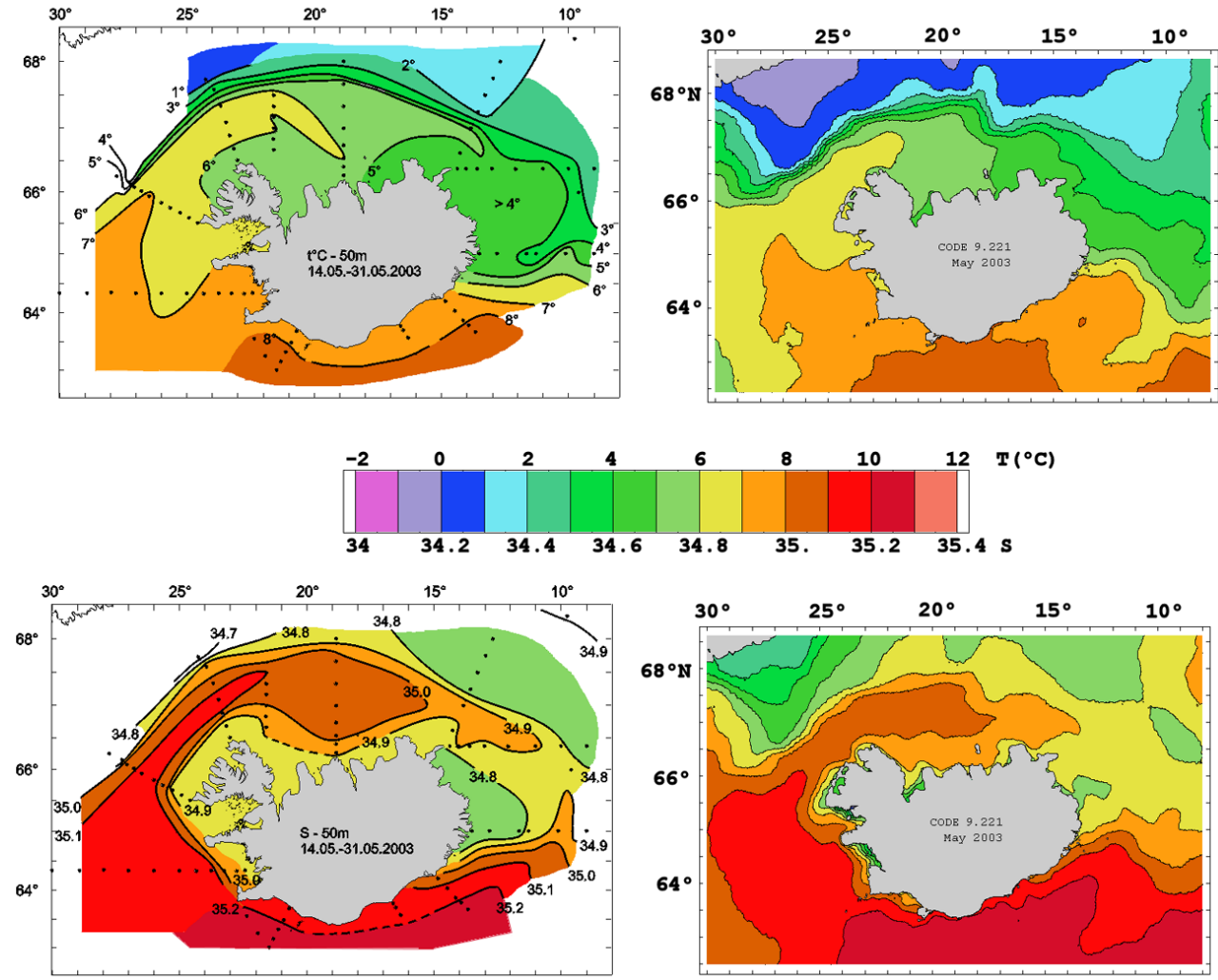

Fig. 4. Observed (left panels) and simulated (right panels) temperature (upper row) and salinity (lower row) in May 2003 at the depth of $50 \mathrm{~m}$. Observational based charts are drawn after charts published by the Marine Research Institute, Iceland (www.hafro.is/Sjora/). The black dots show the location of CTD stations.

salinity in the core of the $\mathrm{FC}$ to be $8.08^{\circ} \mathrm{C}$ and 35.24 during that period. Our simulated equivalents are $7.52^{\circ} \mathrm{C}$ and 35.16 .

Figure 6 shows the simulated mean flow field around Iceland at a depth of $15 \mathrm{~m}$, averaged over the period 1992 to 2006. The striking features are the general eastward flow north and south-east of the island and the contrasting area of sluggish north-westerly flow in the south-west. Figure 7 gives a schematic overview of the simulated threedimensional circulation pattern, denotes different currents and defines 16 analysis sections. The current's mean properties across these sections - volume flux, temperature and salinity - are listed in Table 2.

The definitions of the currents revealed in this study (Fig. 7) are based upon the 1992-2006 mean flow field, i.e., we refer to the long-term mean dynamic structures and do not consider the water mass composition of the flow. These definitions, comprised of positions and directions, were applied to the $12 \times 15$ monthly mean flow, temperature and salinity fields in order to obtain the values listed in Table 2. Occasionally, for reasons of clarity, hitherto unnamed currents are named, strictly following the existing naming system and without any pretence of final validity. In this way, we identified the following currents in Icelandic waters.

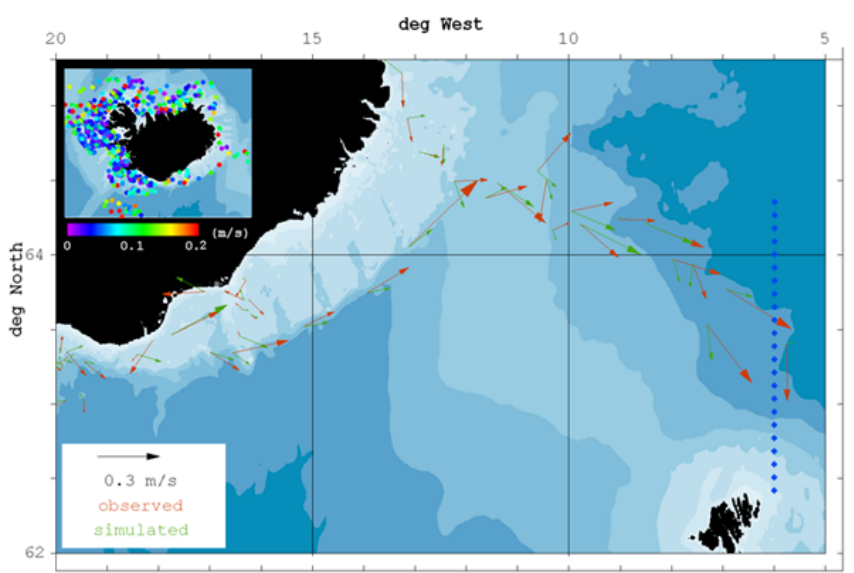

Fig. 5. Observed (red) and simulated (green) drift vectors at $15 \mathrm{~m}$ depth southeast of Iceland between May 1998 and December 1999. Observed vectors are based on the surface drifter experiments by Valdimarsson and Malmberg (1999). The dotted blue line indicates the location of the surveyed cross-FC section (Hansen et al., 2010). Top left: The coloured dots denote the position of all analysed vector pairs. The colour indicates the amount of the vector difference (observed minus simulated drift). 
Table 2. Simulated 1992-2006 mean volume flux, temperature and salinity of the currents in Icelandic waters across the 16 analysis sections. See Figure 7 for the locations of the sections and for the abbreviations of ocean current names.

\begin{tabular}{llrrrlllrr}
\hline Section & Current & $\begin{array}{r}\text { Flux } \\
{[\mathrm{Sv}]}\end{array}$ & $\begin{array}{r}T \\
{\left[{ }^{\circ} \mathrm{C}\right]}\end{array}$ & $S$ & Section & $\begin{array}{l}\text { Current } \\
{[\mathrm{Sv}]}\end{array}$ & $\begin{array}{r}\text { Flux } \\
{\left[{ }^{\circ} \mathrm{C}\right]}\end{array}$ & $T$ & $S$ \\
\hline 1 & ICC & 0.012 & 6.98 & 33.481 & 8 & oNIIC3 & 0.92 & 1.45 & 34.824 \\
1 & ICUC & 0.016 & 6.93 & 34.482 & 8 & NIJ & 1.39 & -0.22 & 34.887 \\
1 & WIIC & 0.20 & 6.98 & 35.043 & 9 & iNIIC & 0.33 & 4.05 & 34.816 \\
1 & IC & 10.62 & 5.89 & 34.937 & 9 & EIC & 1.26 & 2.32 & 34.824 \\
2 & ICC & 0.079 & 6.82 & 34.889 & 9 & NIJ & 1.04 & -0.16 & 34.885 \\
2 & ICUC & 0.049 & 6.35 & 35.060 & 10 & iNIIC & 0.23 & 3.88 & 34.774 \\
3 & ICC & 0.021 & 5.93 & 34.736 & 10 & EIC & 0.90 & 2.55 & 34.802 \\
3 & NIIC & 1.58 & 6.16 & 35.036 & 10 & NIJ & 2.20 & -0.46 & 34.889 \\
3 & OF & 1.33 & 1.18 & 34.894 & 11 & iNIIC & 0.07 & 4.28 & 34.678 \\
4 & iNIIC & 0.30 & 5.95 & 34.963 & 11 & EIC & 0.57 & 2.29 & 34.780 \\
4 & oNIIC & 1.07 & 5.34 & 34.986 & 11 & NIJ & 0.35 & -0.19 & 34.889 \\
4 & NIJ & 1.53 & 0.43 & 34.876 & 12 & SIC & 1.70 & 7.24 & 35.141 \\
4 & EGC & 1.15 & 0.09 & 34.520 & 13 & SIC & 0.70 & 7.53 & 35.140 \\
5 & iNIIC & 0.46 & 5.66 & 34.943 & 13 & ISC & 0.32 & 6.74 & 35.152 \\
5 & oNIIC & 1.68 & 2.56 & 34.859 & 14 & SIC & 0.31 & 7.49 & 35.124 \\
5 & NIJ & 0.96 & 0.21 & 34.881 & 14 & ISC & 1.13 & 7.04 & 35.161 \\
6 & iNIIC & 0.42 & 5.14 & 34.905 & 15 & ICC & 0.010 & 6.74 & 34.585 \\
7 & oNIIC & 2.02 & 2.32 & 34.858 & 15 & ICUC & 0.045 & 7.87 & 35.033 \\
7 & NIJ & 1.23 & 0.09 & 34.868 & 15 & SIC & 0.43 & 7.62 & 35.169 \\
8 & iNIIC & 0.12 & 4.75 & 34.862 & 16 & ICC & 0.033 & 6.86 & 35.007 \\
8 & oNIIC1 & 0.37 & 4.04 & 34.858 & 16 & ICUC & 0.009 & 7.73 & 35.026 \\
8 & oNIIC2 & 0.56 & 2.98 & 34.855 & & & & & \\
\hline
\end{tabular}

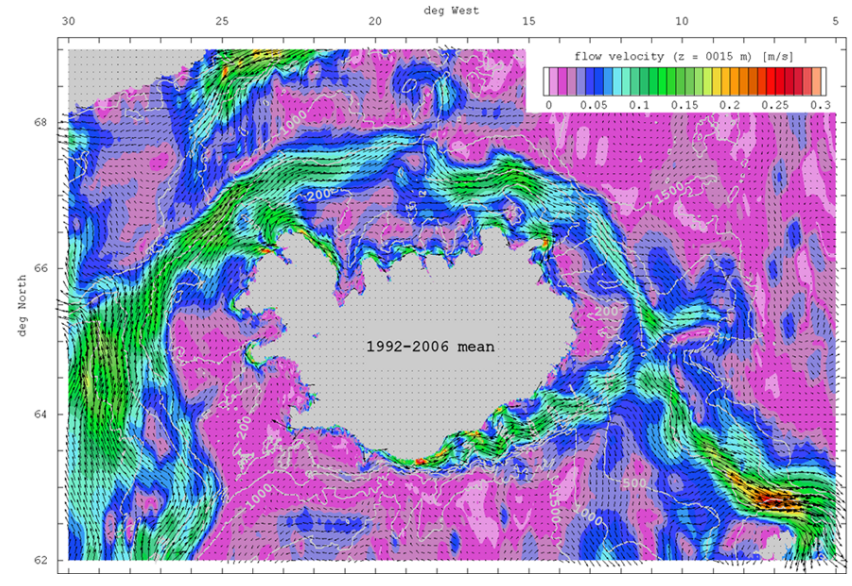

Fig. 6. Simulated mean flow field around Iceland at $15 \mathrm{~m}$ depth, averaged over the period 1992 to 2006 and bottom topography (1500, 1000,500 and $200 \mathrm{~m}$ isobaths).

\subsubsection{Icelandic Coastal Current (ICC) and Icelandic Coastal Undercurrent (ICUC)}

We define the ICC as a near-shore ocean current being driven by the barotropic pressure gradients due to a runoff induced coastal density reduction, therefore directed clockwise around the island. In order to analyse the spread of the coastal freshwater over the Icelandic waters, we computed the sea-

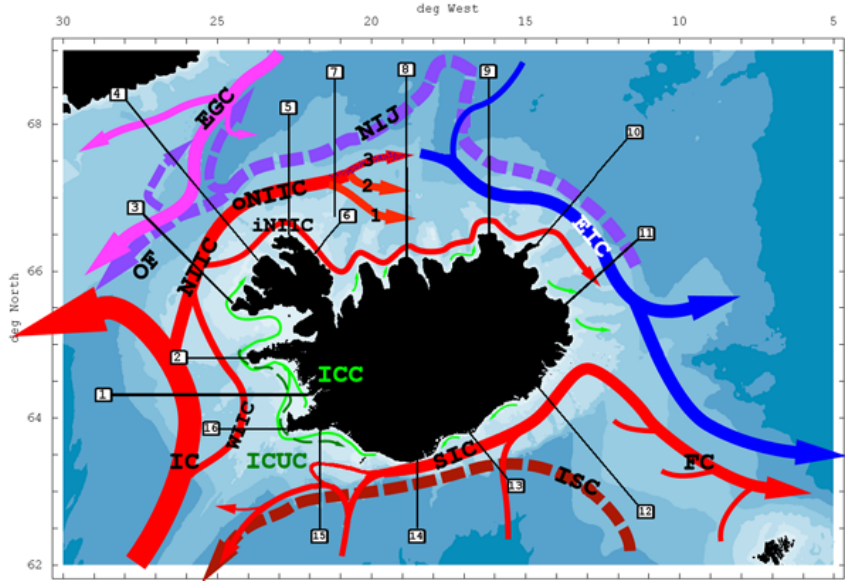

Fig. 7. Proposed three-dimensional circulation scheme of Icelandic waters with the locations of the 16 analysis sections. Dashed arrows denote deep currents. The abbreviations are: EGC - East Greenland Current, EIC - East Icelandic Current, FC - Faroe Current, IC - Irminger Current, ICC - Icelandic Coastal Current, ICUC - Icelandic Coastal Undercurrent, iNIIC - inner NIIC, ISC - Icelandic Slope Current, NIJ - North Icelandic Jet, NIIC - North Icelandic Irminger Current, OF - Overflow, oNIIC - outer NIIC, SIC - South Icelandic Current, WIIC - West Icelandic Irminger Current.

sonal mean freshwater thickness fields. The freshwater thickness $h_{\mathrm{FW}}$ is defined as the hypothetical thickness the layer of 

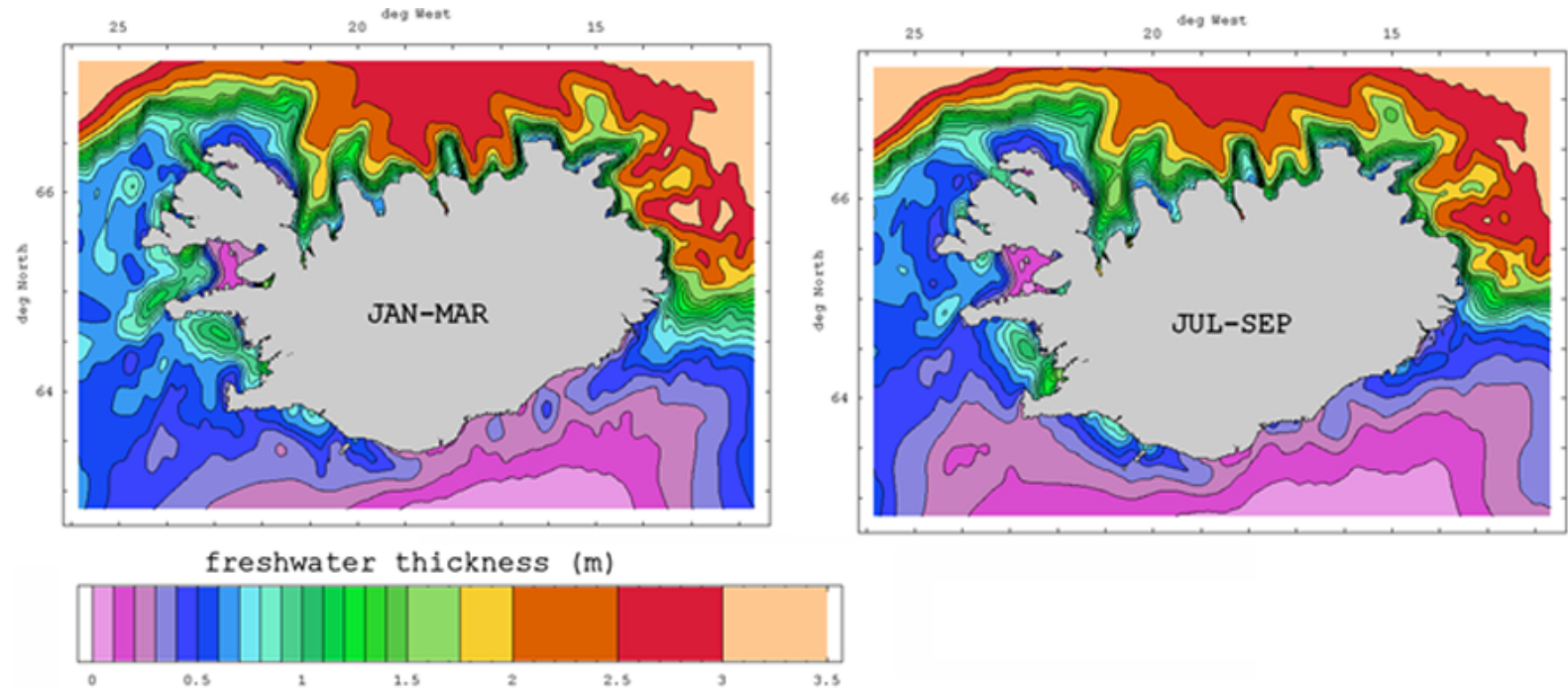

Fig. 8. Mean simulated winter (left) and summer (right) freshwater thickness of Icelandic waters for the time period 1992 to 2006.

freshwater would form if it was separated from the seawater with which it is mixed. By constraining to the upper $300 \mathrm{~m}$ of the water column we used

$h_{\mathrm{FW}}=\int_{z=-300 \mathrm{~m}}^{\mathrm{z}=0 \mathrm{~m}} \frac{S_{\mathrm{REF}}-S(z)}{S_{\mathrm{REF}}} \mathrm{d} z$

with the reference salinity $S_{\mathrm{REF}}=35.2$, which is assumed to be the salinity of pure Atlantic Water. Figure 8 shows the resulting simulated mean winter and summer freshwater thickness fields around Iceland.

Given the seasonality of the discharge (Fig. 3) we find only little seasonal variation of the coastal freshwater thickness. Furthermore, only along the south-west and west coast a clear riverine, near-shore freshwater signal can be detected, whose northern parts are stronger in winter than in summer. Along the south-east coast, despite the great glacial discharge there, hardly any freshwater is found, not even during summer, and along the north coast we see an $h_{\mathrm{FW}}$ minimum in contrast to the high values of the Arctic waters of the Iceland Sea north of it.

Therefore, within the 1992-2006 mean flow and salinity fields, we detected a clear ICC structure apart from several small-scale occurrences in bays and fjords only along the south-west and west coasts.

Originating north-east of the Westman Islands near the mouth of the Markarfljót River, the ICC is amplified between 50 and $100 \mathrm{~km}$ downstream by the discharge of the rivers Hólsá, Pjórsá and Ölfusá (see the row of four blue rectangles along the south-west coast in Fig. 3). With a volume flux usually between 0.01 and $0.03 \mathrm{~Sv}$ the current follows the coastline in a generally north-westerly direction towards Denmark Strait where it finally mixes into the NIIC (Fig. 7). Around the Snæfellsnes peninsula (eastern end of section 2) the ICC
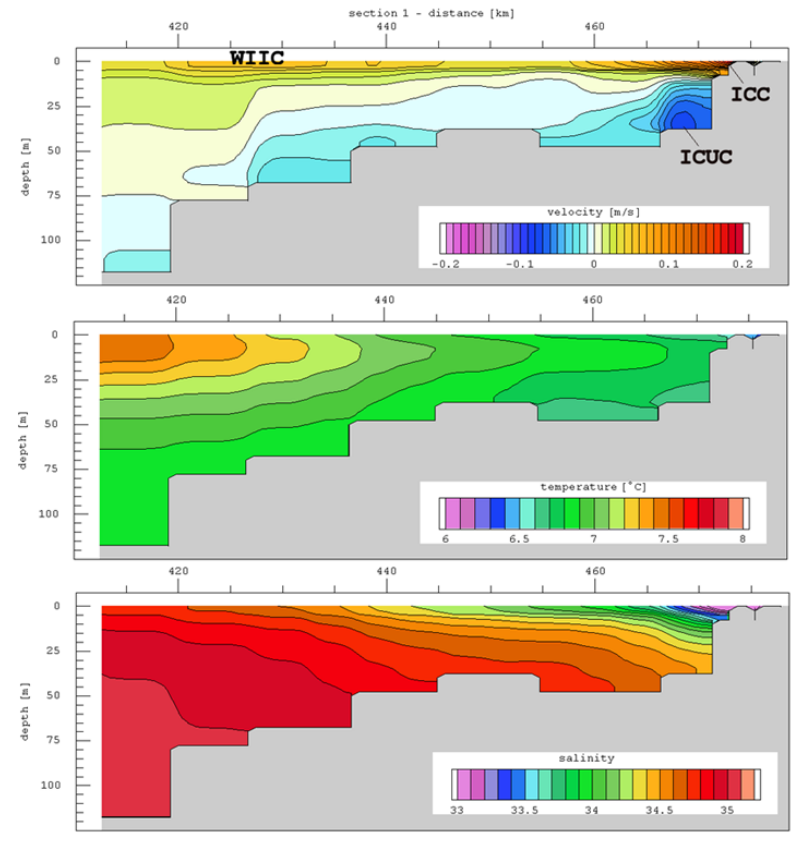

Fig. 9. Simulated 1992-2006 mean of flow (positive (red) values denote northward flow), temperature and salinity across section 1 (eastern end). See Figure 6 for section location.

is exceptionally strong $(0.08 \mathrm{~Sv})$, broad and deep, pumping large amounts of freshened Faxaflói Bay water over the very steep topography to the north.

The general ICC structure is found in our model as a narrow (around $10 \mathrm{~km}$ ) alongshore current, reaching from the sea surface down to the depth between 10 and $30 \mathrm{~m}$, which is associated with a sharp horizontal salinity gradient (Fig. 9). 
Table 3. Percentage change of the August to December 2003 mean volume flux of different currents (superscript number denotes the section) in the sensitivity experiments. Most notable changes are marked with bold numbers. The acronym ADJ denotes the model version with activated CTD data assimilation used for the long run. NIIC ${ }^{4}$ denotes the sum of iNIIC $^{4}$ and oNIIC ${ }^{4}$. In case of experiment NORO only the December 2003 mean fluxes were considered.

\begin{tabular}{lrrrrrrr}
\hline Current & \multicolumn{7}{c}{ Experiment } \\
& ADJ & NOWI & locRHO & gloRHO & NORO & NOTI & NONL \\
\hline EGC $^{4}$ & -2.5 & -15 & $-\mathbf{7 3}$ & -71 & -1 & -23 & -4 \\
EIC $^{11}$ & -2.4 & -2 & -34 & $\mathbf{5 1}$ & +2 & +9 & -8 \\
ICC $^{1}$ & 1.7 & +3 & -50 & -45 & $-\mathbf{8 2}$ & -35 & -9 \\
ICUC $^{1}$ & 0.4 & -30 & -94 & -96 & $-\mathbf{9 7}$ & -33 & +41 \\
NIIC $^{4}$ & -1.7 & 0 & +24 & $\mathbf{- 7 8}$ & +2 & +6 & -7 \\
iNIIC $^{5}$ & 0.3 & +10 & +7 & $\mathbf{- 9 9}$ & -1 & +6 & -8 \\
iNIIC $^{9}$ & 0.7 & +2 & $-\mathbf{5 6}$ & -100 & -11 & -12 & -5 \\
oNIIC $^{5}$ & -4.0 & +14 & +39 & $-\mathbf{1 0 0}$ & +5 & -3 & -7 \\
NIJ $^{7}$ & -29.5 & -5 & $-\mathbf{9 8}$ & -38 & -1 & +35 & -2 \\
SIC $^{14}$ & 2.2 & -13 & +60 & $-\mathbf{6 3}$ & -11 & +16 & -1 \\
ISC $^{14}$ & 0.7 & +35 & $-\mathbf{1 0 0}$ & -100 & +17 & +3 & -1 \\
\hline
\end{tabular}
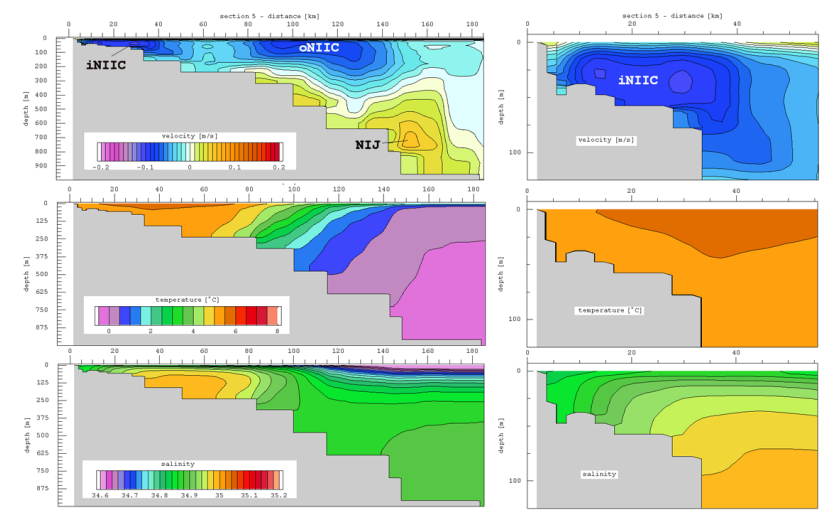

Fig. 10. Simulated 1992-2006 mean of flow (positive (red) values denote westward flow), temperature and salinity across section 5 . See Fig. 6 for section location.

The simulated along-shore variability can be clearly seen by comparing the near-shore flow and salinity fields at section 1 (Fig. 9) and section 5 (Fig. 10). Across section 1 we see the ICC, associated with a sharp salinity increase from below 33 close to the coast to values above $3420 \mathrm{~km}$ further offshore. However, at section 5 is coastal salinity gradient is smaller by one order of magnitude (from 34.8 at the coast to $34.920 \mathrm{~km}$ offshore) and the near-shore, wind-driven current is even directed westward, i.e., to the opposite direction of a potential freshwater driven coastal current.

With the exception of section 1 where the coastal pressure field is probably already dominated by the NIIC, we find the ICC being accompanied with a counter-directed undercurrent which we call the Icelandic Coastal Undercurrent (ICUC) (Figs. 7 and 9). This current has a volume flux comparable to that of the ICC but has a distinctly higher salinity. Its depth range is between 10 and $50 \mathrm{~m}$ and the width is around $10 \mathrm{~km}$.

\subsubsection{Irminger Current (IC) and West Icelandic Irminger Current (WIIC)}

The IC is simulated to be the significantly strongest ocean current in Icelandic waters, flowing along the continental slope west of Iceland (Figs. 6 and 7). Originating along the western flank of the Reykjanes Ridge, the current transports $10.6 \mathrm{~Sv}$ of Atlantic and Subpolar Mode Water which is in good accordance with the Sarafanov et al. (2012) summer transport estimation of $12.0 \pm 3.0 \mathrm{~Sv}$ and below the value of $19 \pm 3 \mathrm{~Sv}$ given by Våge et al. (2011a). Between the continental slope and the Icelandic coast, over the West Icelandic shelf, we find an IC branch which is rather sluggish and broad and herein called the West Icelandic Irminger Current (WIIC) (Fig. 7). Note that in Fig. 7 the schematic source path of the WIIC contains a substantial cross-isobath component. Hence, the corresponding flow should not be understood as continuous and straight but, according to Valdimarsson (1998), rather as sluggish and eddy-induced. Figure 9 shows this current flowing across section 1 with its core close to the surface between 420 and $445 \mathrm{~km}$. The WIIC originates over the continental slope north of the Reykjanes Ridge and flows northward over the western shelf until it finally joins the NIIC in Denmark Strait. The mean volume flux is $0.2 \mathrm{~Sv}$, the temperature varies seasonally between 6 and $9{ }^{\circ} \mathrm{C}$ and the salinity is slightly above 35 .

\subsubsection{North Icelandic Irminger Current (NIIC), North Icelandic Jet (NIJ) and East Icelandic Current (EIC)}

Having reached the southern Denmark Strait the IC is deflected to the west by the Greenland-Iceland Ridge and finally recirculates southward along the Greenland continental slope. Forming the NIIC a fraction of around 1.4 Sv branches 


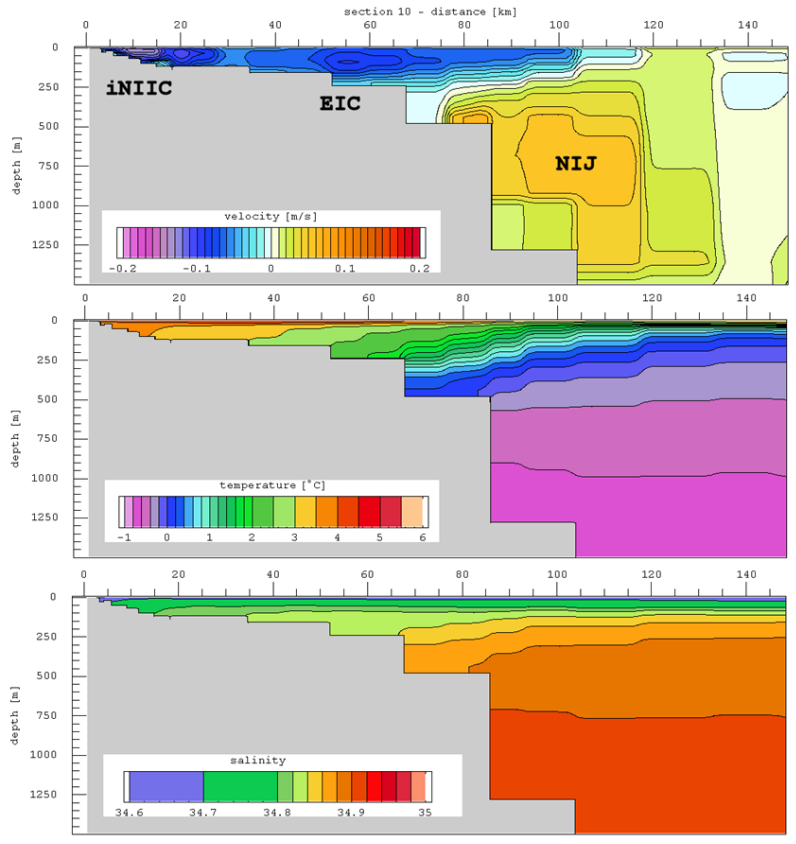

Fig. 11. Simulated 1992-2006 mean of flow (positive (red) values denote north-westward flow), temperature and salinity across section 10. See Fig. 6 for section location.

off in Denmark Strait and flows northward along the Icelandic shelf edge, which again is in agreement with observations (Kristmannsson, 1998; Jónsson and Valdimarsson, 2005). This current absorbs the WIIC $(\approx 0.2 \mathrm{~Sv})$ in southern Denmark Strait. Shortly after crossing the Denmark Strait Sill, having lost around $0.2 \mathrm{~Sv}$ to the southwards flowing EGC, the NIIC splits into an inner (iNIIC $\approx 0.3 \mathrm{~Sv}$ ) and an outer branch (oNIIC $\approx 1.1 \mathrm{~Sv}$ ).

Whereas the iNIIC flows eastward along the North Icelandic coast, the oNIIC takes an outer eastward route along the North Icelandic continental slope. The iNIIC can be traced downstream to the east coast of Iceland which is occasionally also reached by parts of the oNIIC. However, within the simulated long term mean, the oNIIC, after leaving Denmark Strait where some mixing with the Polar Water of the EGC occurs, broadens and increases its volume flux by entrainment of Arctic waters $(1.1 \mathrm{~Sv}$ at section $4,1.7 \mathrm{~Sv}$ at section 5, 2.0 Sv at section 7). Before reaching the Kolbeinsey Ridge the oNIIC divides into three branches where the northernmost branch $(\approx 0.9 \mathrm{~Sv})$ with a mean temperature below $1{ }^{\circ} \mathrm{C}$ and a salinity close to 34.8 already shows more Arctic than Atlantic Water characteristics which may cast into doubt its denotation as an NIIC branch.

East of the Kolbeinsey Ridge the three oNIIC branches partly join the Arctic and Polar waters of the EIC which flows southward along the eastern flank of the ridge. Another interpretation of our model results would be to describe the EIC as a continuation of the oNIIC with some intrusion of Arctic and Polar waters flowing southwards along the east-

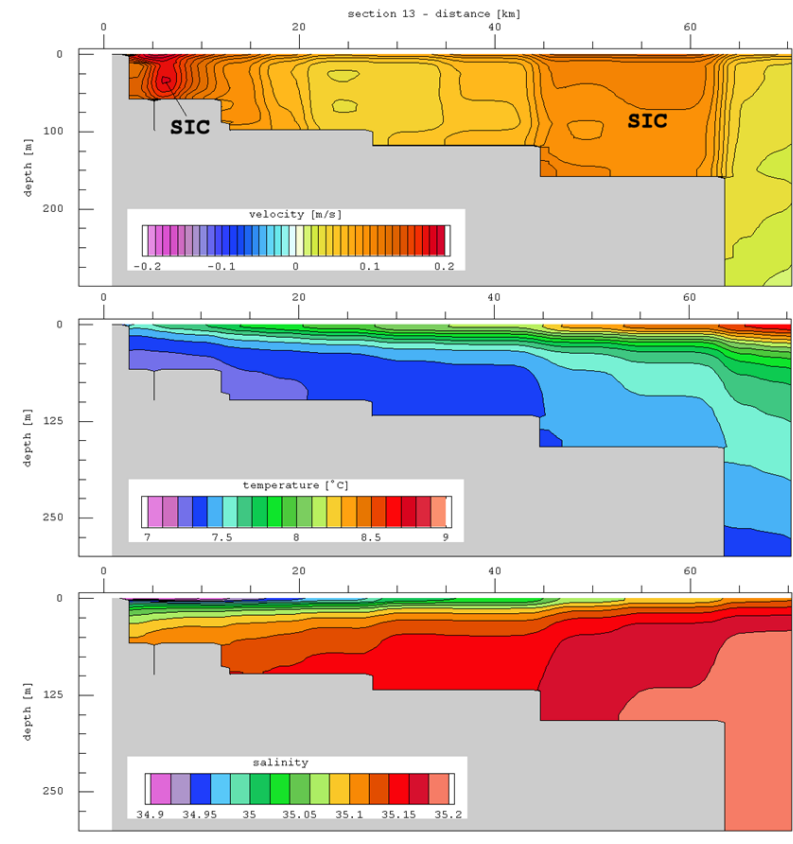

Fig. 12. Simulated 1992-2006 mean of flow (positive (red) values denote north-eastward flow), temperature and salinity across section 13. See Fig. 6 for section location.

ern flank of the ridge (Figs. 6 and 7). With a volume flux of around $1 \mathrm{~Sv}$ the EIC follows the continental slope to the east and continues along the northern flank of the Iceland-Faroe Ridge.

Below the EIC we find a counter-directed, cold $(-0.5$ to $0.4^{\circ} \mathrm{C}$ ) and salty (34.876 to 34.889 ) undercurrent; the NIJ (Figs. 7 and 11). Flowing westward along the continental slope at a depth between 200 and $1000 \mathrm{~m}$, the current reaches a volume transport above $2 \mathrm{~Sv}$ east of the Kolbeinsey Ridge (section 10). After crossing the ridge the volume transport is reduced to $1.4 \mathrm{~Sv}$ (section 8) and continues to decrease as the flow is approaching northern Denmark Strait. However, through section 5 we still see an NIJ of $0.96 \mathrm{~Sv}$ with a temperature of $0.2^{\circ} \mathrm{C}$ and a salinity of 34.881 . Further downstream, across section 4 , the NIJ is simulated to swell up to $1.53 \mathrm{~Sv}$. Then, the NIJ opens out into the Denmark Strait Overflow (OF) a bottom-intensified and density-driven flow down the southern flank of the Greenland-Iceland sill forming a major part of the Meridional Overturning Circulation's lower limb. The mean OF volume flux was simulated to be $1.33 \mathrm{~Sv}$.

\subsubsection{South Icelandic Current (SIC) and Icelandic Slope Current (ISC)}

Over the southern and south-eastern Icelandic shelf the model shows an intense flow of Atlantic Water $\left(7.0-7.6^{\circ} \mathrm{C}\right.$, $35.12-35.17)$ towards the east and north-east, respectively. This boundary current, herein after called the South Icelandic Current (SIC), has highest current speeds over the narrow 


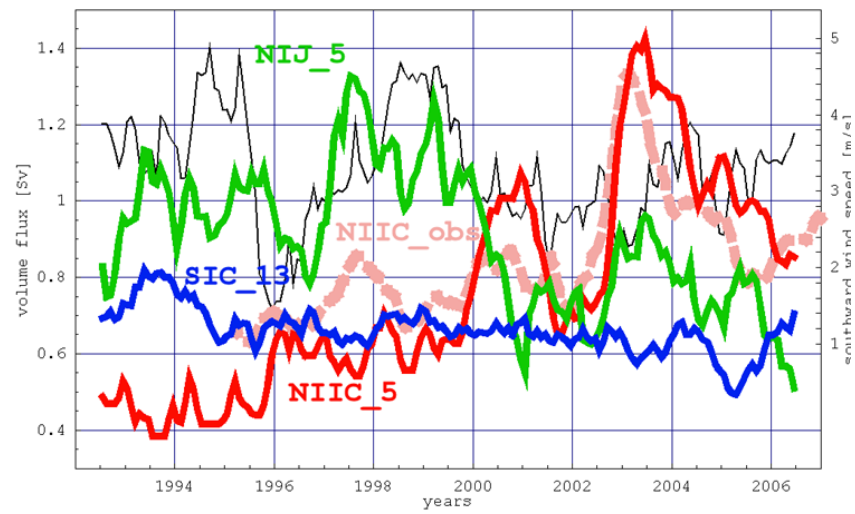

Fig. 13. Time series (13-months moving average) of simulated and observed volume fluxes around Iceland and of the southward wind component (10 m height) north of Denmark Strait (black curve). Green: simulated North Icelandic Jet (NIJ) across section 5; red: simulated Atlantic Water $\left(T>4.5^{\circ} \mathrm{C}\right)$ transport of the North Icelandic Irminger Current (NIIC) across section 5; light red dashed: Atlantic Water transport of the NIIC close to section 5 derived from current meter data (after Jónsson and Valdimarsson, 2012); blue: simulated South Icelandic Current (SIC) across section 13.

shelf at the southernmost tip of Iceland at around $19^{\circ} \mathrm{W}$ : more than $20 \mathrm{~cm} \mathrm{~s}^{-1}$ averaged over the 1992-2006 period (see Fig. 6). Here, the near surface core of the current is found less than $5 \mathrm{~km}$ south of the coastline. Like the WIIC the SIC is fed by the eddy-induced and sluggish northward flow of Atlantic Water south of Iceland which contains crossisobath components shown schematically in Fig. 7. Further downstream the current flows further offshore and broadens as the shelf broadens. Thereby additional Atlantic Water is entrained leading to an increasing SIC volume transport towards the east: $0.3 \mathrm{~Sv}$ at section $14,0.7 \mathrm{~Sv}$ at section 13 and $1.7 \mathrm{~Sv}$ at section 12 . The current is nearly unaffected by horizontal density gradients and therefore shows a homogeneous velocity profile from the surface down to the sea floor (Fig. 12). Figure 12 also indicates that the SIC consists of an inner and an outer branch. Finally, having reached the Iceland-Faroe Ridge, the SIC turns to a south-easterly direction, follows the ridge and opens out into the Faroe Current (FC). The FC volume flux north of the Faroe Islands was simulated to be $2.1 \mathrm{~Sv}$. Hence, we conclude that 15,33 and $81 \%$ of its water stem from the SIC crossing section 14,13 and 12 , respectively.

Along the south-eastern continental slope of Iceland, at the depth between 500 and $1100 \mathrm{~m}$, with the core at around $800 \mathrm{~m}$, our model shows a topographically steered deep counter-current, herein called the Icelandic Slope Current (ISC) (Fig. 7). The ISC consists of re-circulating deeper Atlantic Water which explains the increase of its volume flux between section $13(0.32 \mathrm{~Sv})$ and section $14(1.13 \mathrm{~Sv})$.

\subsubsection{Inter-annual variability of the NIIC, NIJ and SIC}

Our results show that in 2003 the NIIC volume flux, in terms of the 13-months moving average, reached its absolute maximum of the period from 1992 to 2006 (Fig. 13). We obtain the same result when expanding the period's end from 2006 to 2010 by taking into account of the observational records of Jónsson and Valdimarsson (2012). A comparison of the modelled and observed NIIC is given in Fig. 13. Here, regarding the time interval July 1995 to June 2006, the simulated mean NIIC volume flux is $0.84 \mathrm{~Sv}$ whereas the observational based equivalent is $0.85 \pm 0.13 \mathrm{~Sv}$ (Jónsson and Valdimarsson, 2012). Pearson's correlation between the two time series is 0.77 . Note that in Fig. 13, only the Atlantic Water content of the NIIC is considered which was computed with a $T>4.5^{\circ} \mathrm{C}$ criterion applied to the sum of the iNIIC and oNIIC crossing section 5. Our simulation shows an $85 \%$ increase of the multi-annual mean NIIC; the simulated flux of Atlantic Water across section 5 was $0.54 \mathrm{~Sv}$ during the period 1992 to 1999 and rose to $1.00 \mathrm{~Sv}$ during 2001 to 2006.

The NIJ volume flux across section 5 shows a period of rather high transport, $1.03 \mathrm{~Sv}$ during 1992 to 1999 , which is followed by a phase of weaker transport, $0.75 \mathrm{~Sv}$ during 2001 to 2006; a decrease of $27 \%$. Figure 13 also shows the development of the southward wind component north of Denmark Strait (at the position $67^{\circ} 40^{\prime} \mathrm{N}, 22^{\circ} 32^{\prime} \mathrm{W}$ where Logemann and Harms (2006) found a correlation of 0.857 between the meridional wind stress and the NIIC). We see a period of strong southward wind, strong NIJ and weak NIIC during 1997 to 2000. Afterwards these conditions are reversed.

The SIC across section 13 shows the same "remarkably stable" behaviour, at least between 1995 to 2002, as that of the FC analysed by Hansen et al. (2003). The SIC transport through section 13, which solely consists of Atlantic Water, was simulated to be $0.69 \mathrm{~Sv}$ during the period 1992 to 1999 , clearly above the simulated NIIC Atlantic Water transport at that time.

\section{Sensitivity experiments}

In order to examine the forcing mechanism behind the different simulated currents, a series of sensitivity experiments was carried out. First, the data assimilation routine was deactivated, the model was restarted at 12 July 2003 and a simulation until the end of 2003 was performed. This output, not disturbed by the corrections towards observations but fully consistent with the physical model equations, was used as the reference. A comparison of this solution with the original, including data assimilation, showed only minor deviations (experiment ADJ in Table 3) which ensures that the reference run is still realistic with just the NIJ being intensified by $29.5 \%$.

The "local area" was then defined, i.e., the area where different forcing terms were switched off within various 


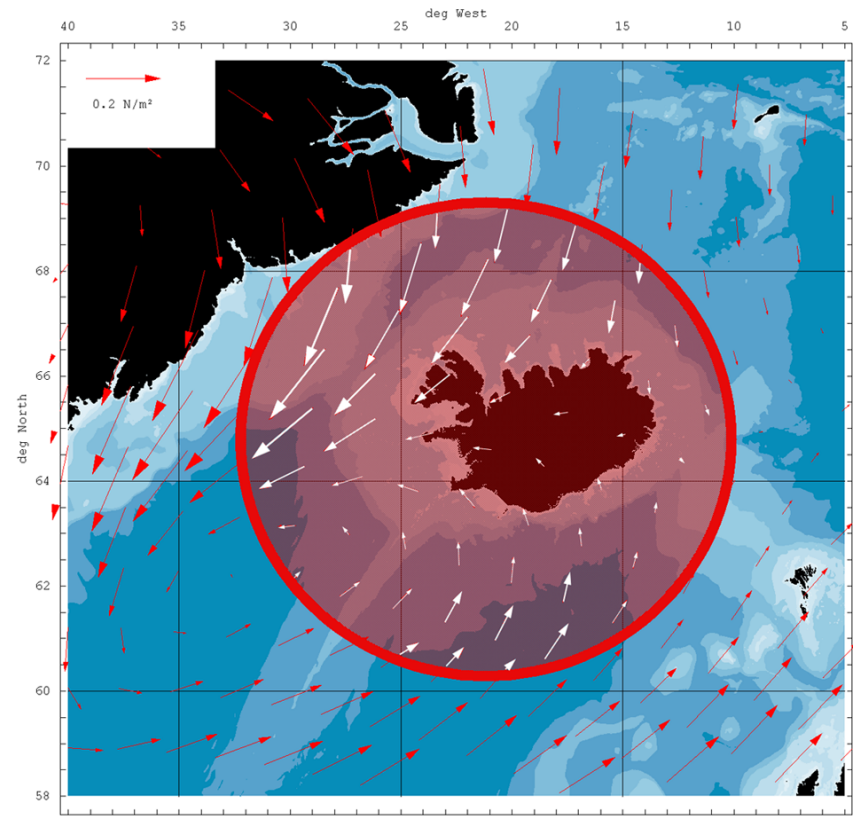

Fig. 14. Bathymetry and mean surface wind stress averaged over the period 1992 to 2006 . In the frame of the various sensitivity experiments different forcing terms were switched off within the red encircled area.

sensitivity experiments. We decided on a circular area having its centre at $64^{\circ} 36^{\prime} \mathrm{N}, 20^{\circ} 56^{\prime} \mathrm{W}$, a radius of $512 \mathrm{~km}$ and a transition ring with the width of $64 \mathrm{~km}$ at its boundary where the abnormal inner conditions were linearly led back to normality (see Fig. 14).

The following six model runs, simulating the same time period as the reference run, were carried out:

1. NOWI - no wind stress in the local area

2. locRHO - no horizontal density gradients in the local area

3. gloRHO - no horizontal density gradients in the entire model domain

4. NORO - no Icelandic river runoff

5. NOTI - no tidal forcing in the entire model domain

6. NONL - no momentum advection in the entire model domain

For each model run the August to December 2003 mean flow field and the corresponding difference of volume flux at each section relating to the reference run was computed. In the case of experiment NORO, because of the retention time of the freshwater within the coastal area, in order to obtain a maximum signal, we compared only the mean December flow fields.
The following interpretation of the six sensitivity experiments is based on the assumption that a significant reduction of a current's flow rate, caused by the deactivation of a specific term, points towards an important role of the related physical process in forcing the current. We have listed a selection of relative volume flux changes of the different currents within the different experiments in Table 3 where the most significant results are marked with bold numbers. These indicate that:

- None of the currents are primarily driven by the local wind stress. Figure $15 \mathrm{~d}$ shows the wind stress impact on the flow field in the depth of $15 \mathrm{~m}$. The main structure is a rather weak westward, near-shore flow north and south of Iceland, a westward flow in the Iceland Sea and a south-westward EGC enforcing component along the East Greenland coast. Note that these results refer to the specific time period August to December 2003. The wind field has a strong influence on the formation of the coastal freshwater induced salinity front which may explain the sensitive reaction of the ICUC, the reduction by $30 \%$ at section 1 , in experiment NOWI.

- The ICC and ICUC were reduced by 82 and $97 \%$, respectively in experiment NORO and hence are primarily driven by pressure gradients due to coastal density reduction caused by river runoff. However, tideinduced residual currents and the wind stress are also important. Figure 16a and c show the dynamic effects of river runoff and tides, respectively. Whereas the tide-induced residual currents become relevant close to some headlands and along the south coast, counteracting the SIC, the runoff-induced effects are very small along the southeast and northwest coast. However, along the southwest and north coast a clear freshwater signature is visible driving the ICC/ICUC and enforcing the iNIIC, respectively. Experiment locRHO (Fig. 16b) indicates that also the WIIC is related to coastal but further offshore density gradients.

- The EGC in Denmark Strait is mainly driven by barotropic pressure gradients related to the Polar Front. Deleting the local horizontal density gradients in experiment locRHO led to an EGC volume flux reduction of $73 \%$. Figure $16 \mathrm{~b}$ shows the dynamic impact of the local density field. Almost the entire EGC signal can be seen. Further forcing results from the tidal residual currents $(23 \%)$ and the local wind stress $(15 \%)$.

- The iNIIC over the north-eastern shelf, the NIJ and the ISC, being reduced in experiment locRHO by 56,98 and $100 \%$, respectively, are therefore assumed to be driven by pressure gradients resulting from local density gradients. In contrast, however, the volume flux of 

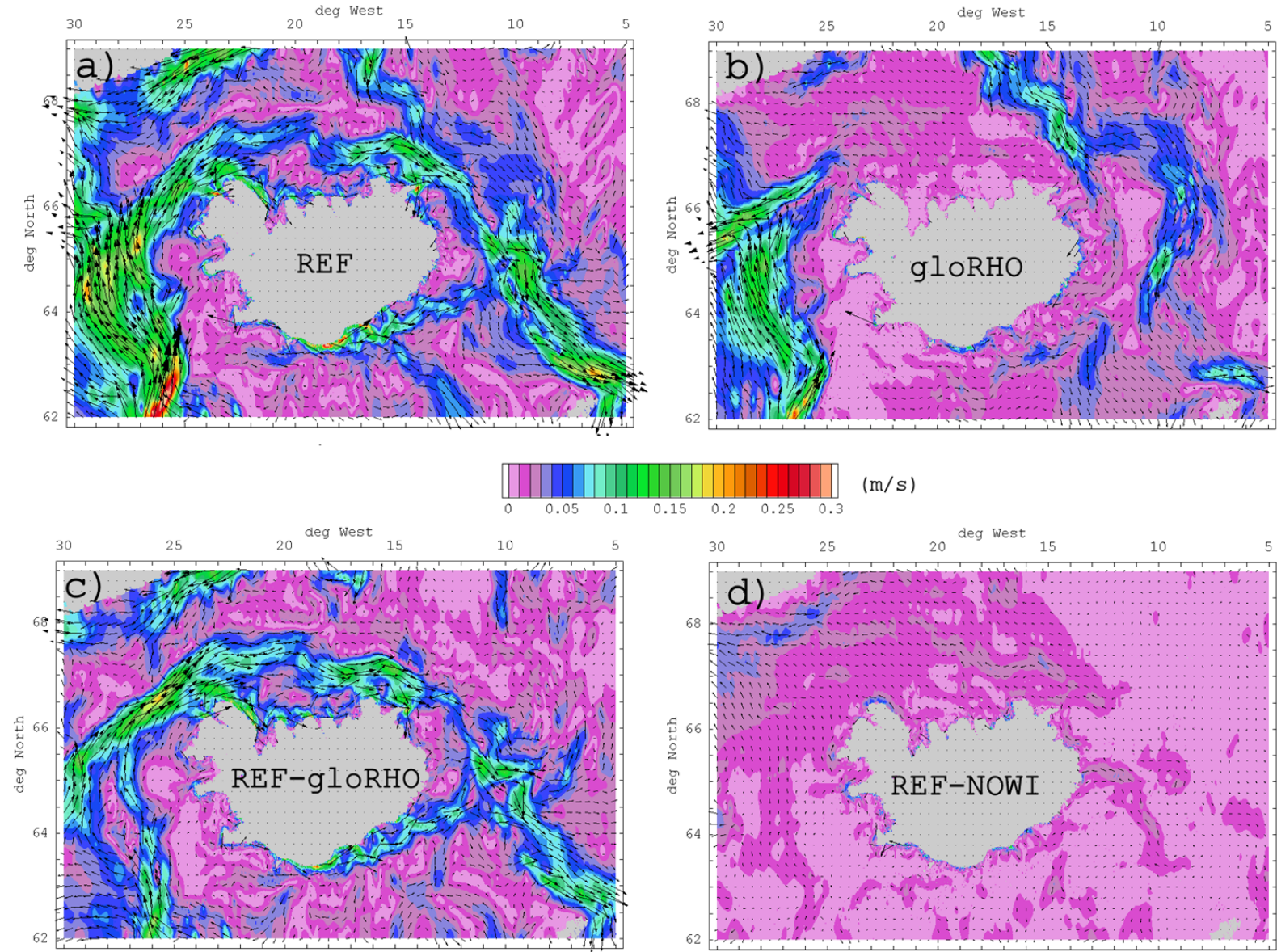

Fig. 15. Results of the sensitivity experiments gloRHO and NOWI. August 2003 to December 2003 mean flow fields at the depth of $15 \mathrm{~m}$ simulated by (a) the reference run and (b) the experiment gloRHO. (c) Shows the difference of both fields (gloRHO subtracted from the reference run). (d) Shows the results of experiment NOWI subtracted from the reference run.

the NIIC in Denmark Strait and of the SIC increased in experiment locRHO by 24 and $60 \%$, respectively, indicating that the local density field is not a critical factor of the basic NIIC/SIC structure.

- Not more than $10 \%$ of the NIIC in Denmark Strait can be explained by the inertia of the IC along its curved path south of the strait. The NIIC reduction in experiment NONL varies between 5 and $8 \%$ (Fig. 16d).

- The NIIC and SIC are predominantly driven by the barotropic pressure field related to the Arctic Front.

This last conclusion was drawn when observing the immediate shutdown of the currents when horizontal density gradients were removed from the entire model domain (experiment gloRHO), whereas both currents increased when only the local density gradients were removed (experiment locRHO). Hence, our sensitivity experiments pointed towards the basin-scale pressure field, i.e., the difference of the sea surface height between the colder and denser waters to the north and the warmer waters to the south of Iceland, being the main forcing factor of the currents. In order to further illuminate this point an additional model experiment was carried out.

\subsection{NIIC/SIC forcing experiment}

In order to understand the nature of the NIIC and SIC forcing, we set up a very simple hydrodynamic scenario:

- a rectangular ocean basin at the reference latitude of $65^{\circ} \mathrm{N}$ with closed boundaries and side lengths of $1600 \times 1600 \mathrm{~km}$;

- an undisturbed ocean depth of $3000 \mathrm{~m}$ and a circular island of the radius of $210 \mathrm{~km}$ in the centre of the basin described by

$$
D(r)=500 \mathrm{~m}\left(1-\tanh \left(1.0472 \times 10^{-5} \mathrm{~m}^{-1} r-\pi\right)\right)
$$

with $r$ being the distance from the basin centre (see Fig. 17a); 

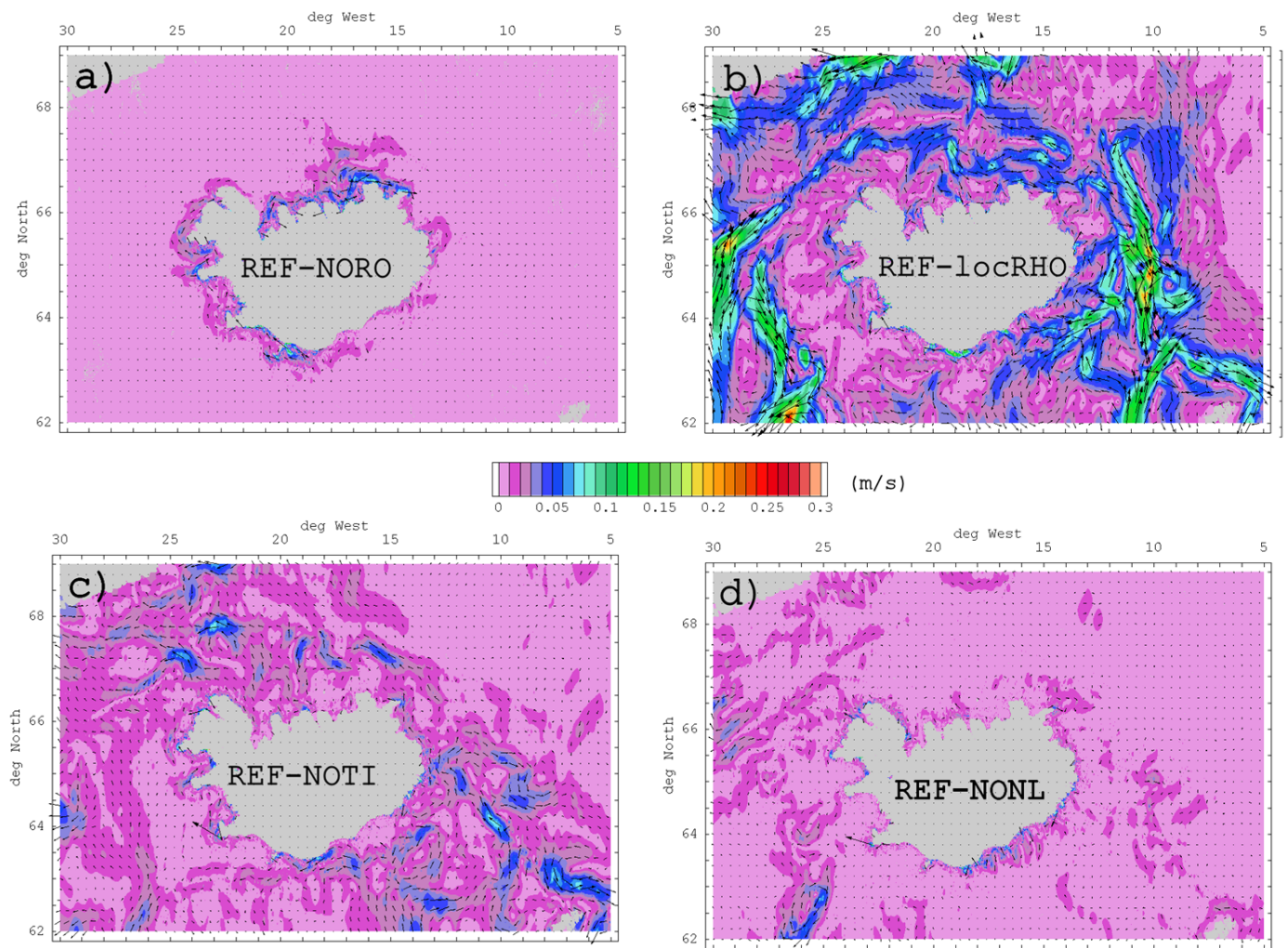

Fig. 16. Results of the sensitivity experiments NORO, locRHO, NOTI and NONL. Simulated mean flow fields at the depth of $15 \mathrm{~m}$ subtracted from those of the reference run. Difference vector fields relating to (a) December 2003 mean of experiment NORO, (b), (c) and (d) August 2003 to December 2003 means of experiments locRHO, NOTI and NONL, respectively. Note that the results of experiment locRHO are only relevant within the local area (Fig. 14).

- a zonal, stationary density front separating denser water with $1028.4 \mathrm{~kg} \mathrm{~m}^{-3}$ in the north from less dense water with $1027.9 \mathrm{~kg} \mathrm{~m}^{-3}$ in the south, roughly describing the conditions around Iceland. The meridional density profile is given by

$$
\rho(y)=1027.9 \mathrm{~kg} \mathrm{~m}^{-3}+0.25 \mathrm{~kg} \mathrm{~m}^{-3}\left(1+\tanh \left(\frac{y-800 \mathrm{~km}}{30 \mathrm{~km}}\right)\right)
$$

with $y$ being the meridional distance from the southern boundary (see Fig. 17a).

The solution of this problem was determined with a simplified version of the CODE model, using a homogenous horizontal grid with a spacing of $10 \mathrm{~km}$ and $37 z$ levels with a vertical spacing from $10 \mathrm{~m}$ near the sea surface to $160 \mathrm{~m}$ close to the sea floor. Using a time step of $30 \mathrm{~s}$ the model was spun up by linearly raising the density gradients from zero to the prescribed values during the first simulated week. The density gradients caused hydrostatic pressure gradients. These caused a southward flow which raised the sea level south of the front until the related near-surface northward flow balanced the southward. Quasi-stationary, mainly geostrophic conditions were achieved shortly afterwards (Fig. 17b-d).
Figure 17b shows the difference of sea surface height between the northern (lower level) and southern (higher level) part of the basin due to the density difference. Like the density the sea surface height forms a front which is, distant from the island, on top of and parallel to the density front. The resulting pressure gradient force leads to an upper layer geostrophic eastward flow along the front (Fig. 17c). A counter-current is found in deeper layers (Fig. 17d).

However, close to the island, this structure is distorted. When hitting the island, the upper eastward flow causes a zone of high pressure at the island's western (windward) coast and a low pressure zone at the eastern (lee side) coast. These pressure anomalies spread along the coast in the Kelvin wave propagation direction. The consequences are two geostrophic northward currents along the west and the east coast, extending to the north and south coast, respectively. These two currents have a clear similarity to the NIIC and SIC.

In order to examine the role of the island topography in the formation of this NIIC/SIC structure we performed two further experiments. First, we used a topography with a very steep slope and no shelf (Fig. 18a) and thereafter a topography with a well-defined shelf (Fig. 18d). The results (Fig. 18b, c, e, f), i.e. the missing NIIC/SIC structure 

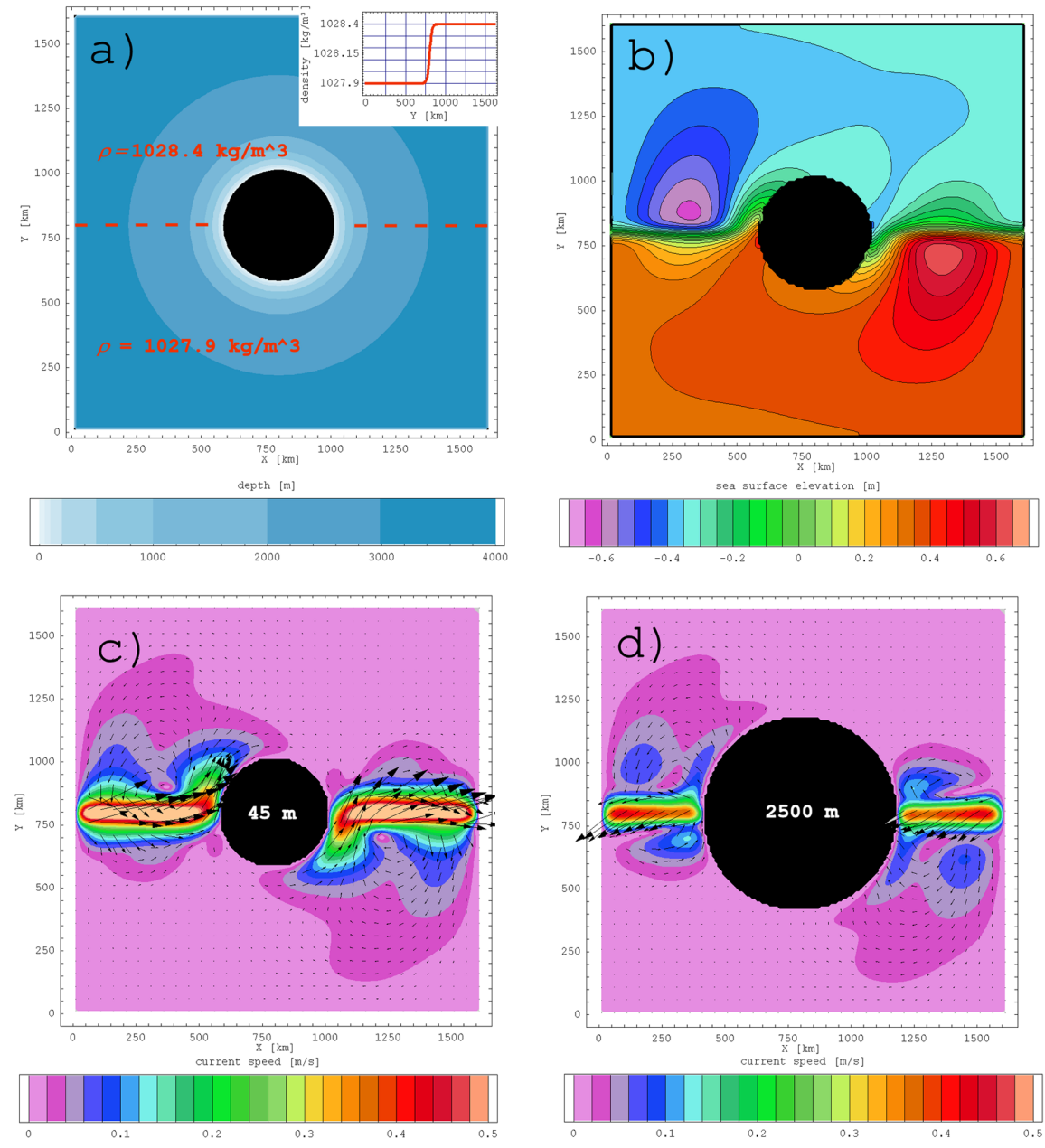

Fig. 17. Setup and results of the NIIC/SIC forcing experiment. (a) Topography and prescribed stationary density field, (b) stationary sea surface elevation after the spin-up, (c) stationary flow field at the depth of $45 \mathrm{~m}$, (d) stationary flow field at the depth of $2500 \mathrm{~m}$.

in the first case and its amplification in the second, show that a shelf, i.e. a sufficiently broad coastal area with significantly reduced water depth, is a prerequisite of the NIIC/SIC structure.

\section{Discussion and conclusions}

In this paper we have analysed a hydrodynamic simulation of Icelandic waters covering the time period 1992 to 2006. Thereby, we have concentrated particularly on the temporal mean state derived from the model output. However, we also presented the simulated temporal variability of the involved ocean currents which partly contains considerable inter-annual fluctuations. Furthermore, we know that the regional marine climate occasionally has undergone dramatic changes (Malmberg and Kristmannsson, 1992). Hence, this paper should not be understood as an attempt to specify ever- fitting structures of a stationary system, but rather as a proposed description of the current state.

The model results indicate that within the long-term mean flow field a distinct Icelandic Coastal Current (ICC) exists only to the south-west of Iceland. Only in this coastal region between the Westman Islands to the south and the Látrabjarg tongue to the north, are the coastal waters sufficiently protected from a direct flushing of Atlantic Water and the freshwater discharge sufficiently large to enable the almost persistent formation of the coastal freshwater-induced density front. North of Látrabjarg and further downstream along the north-west and north coast, the North Icelandic Irminger Current (NIIC) dominates the near-shore circulation and erodes most of the coastal freshwater signatures. However, in more shielded areas like the Húnaflói Bay or within the large western and northern fjords, the ICC shows sporadic appearances which is in agreement with observations (Ólafsson et al., 2002). This also applies, to a lesser extent, to the south-east coast. Here, a counter-directed, intense 

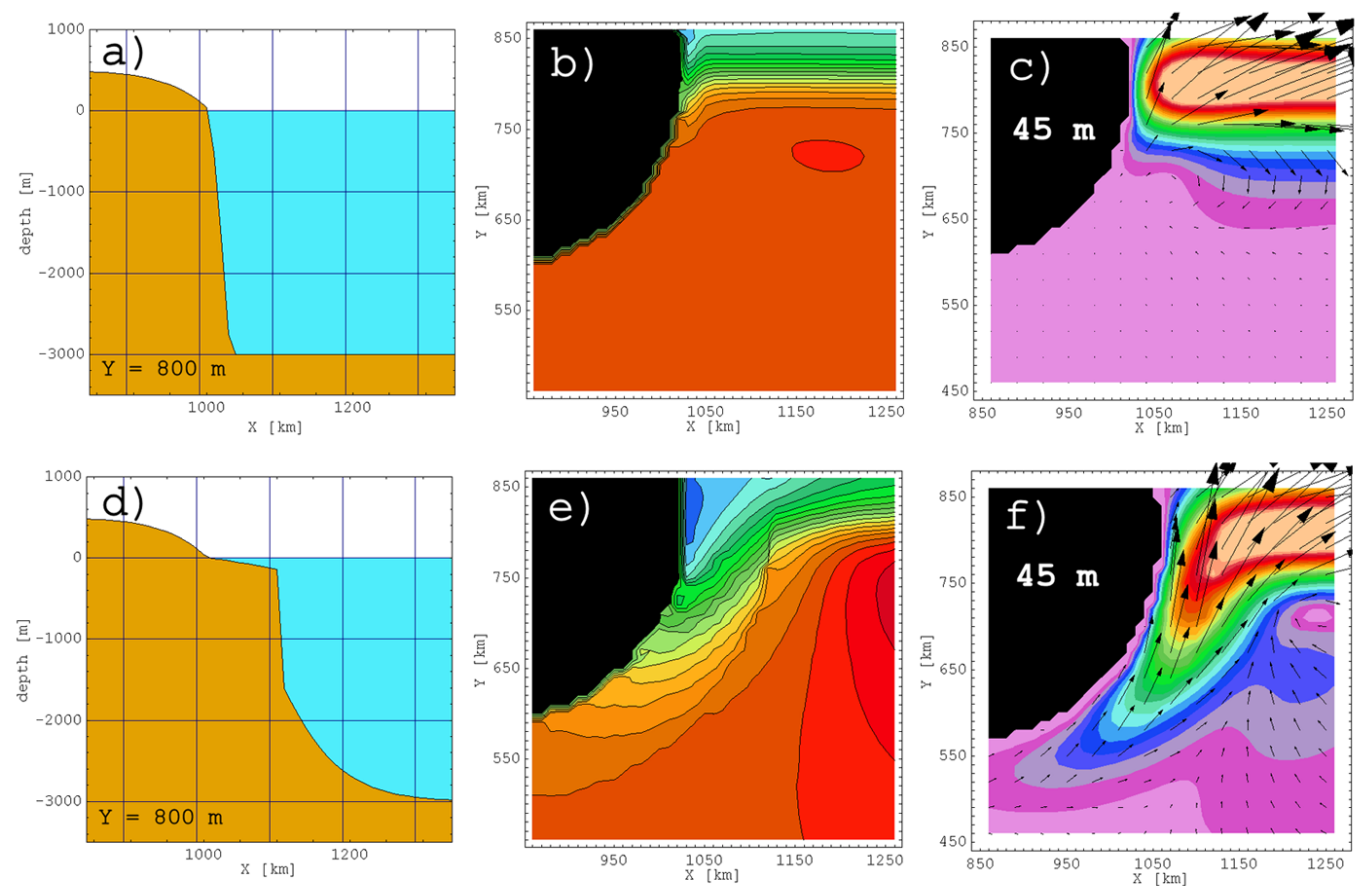

sea surface elevation $[\mathrm{m}]$
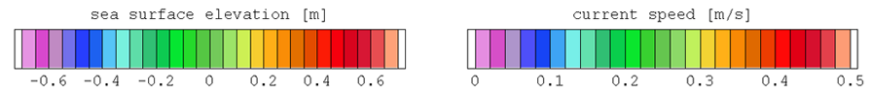

Fig. 18. Results of the NIIC/SIC forcing experiment performed with two different topographies. Stationary solutions after the spin-up are shown. (a) The topography without a shelf, (b) the resulting sea surface elevation, (c) the resulting flow field at the depth of $45 \mathrm{~m}$, (d) the topography with a wide shelf, (e) the resulting sea surface elevation, and (f) the $45 \mathrm{~m}$ flow field for this case.

north-eastward boundary current of Atlantic Water not only erodes the coastal freshwater signature but also counteracts the development of a south-westward flow.

Hence, our model results offer a solution to the ICC quandary, which is defined by two opposing schemes of the coastal circulation around Iceland: (a) the classical view of a freshwater-induced current flowing clockwise around the island (e.g., Stefánsson and Ólafsson, 1991; Halldórsdóttir, 2006); and (b) the assumption that freshwater-induced nearshore dynamics do not form a separate current, with the coastal circulation instead thought to derive from the offshoots of the larger ocean currents further off-shore (e.g., Astpórsson et al., 2007). Our findings point to the possibility that both views are correct when applied to different coastal sections. They illustrate the transport of freshwater along the south-west coast in accordance with the measurements of Stefánsson and Guðmundsson (1978) and Ólafsson et al. $(1985,2008)$, but also explain the sparse occurrence of polar driftwood at south-eastern beaches which is in sharp contrast to the large deposits often found at north-eastern beaches (Eggertsson, 1994) - an observation that indicates the absence of a steady southward current connecting these areas.

Another result of this study is the possible existence of an undercurrent below the ICC, which we have called the Ice- landic Coastal Under-Current (ICUC). Unfortunately there are no long-term current measurements from the depth range within the shallow near-shore waters along the south-west coast where we predict the ICUC to occur. We are therefore unable to confirm or refute our model predictions; however, the simulated structure is compatible with the theoretical predictions of ocean physics. These predict a counterdirected undercurrent if an along-shore density front exists which reaches down to the bottom-boundary layer (Chapman and Lentz, 1994; Pickart, 2000).

One might wonder whether the simulated undercurrent could have been caused by a numerical error which appears along the boundary between domains of different mesh refinement. The background of this question forms the widespread assumption of trapped or reflected kinetic energy at those boundaries in adaptive mesh ocean models (Griffies et al., 2000). However, in accordance with Popinet and Rickard (2007) we found the main reason for this problem to be the formulation of the discrete spatial operators, i.e., their accuracy and smoothness, across the resolution boundaries. Furthermore, regarding the model solution discussed here, the ICUC as a numerical error would raise the questions why its magnitude is realistic (in the range of the ICC) and why it appears only where it is physically 

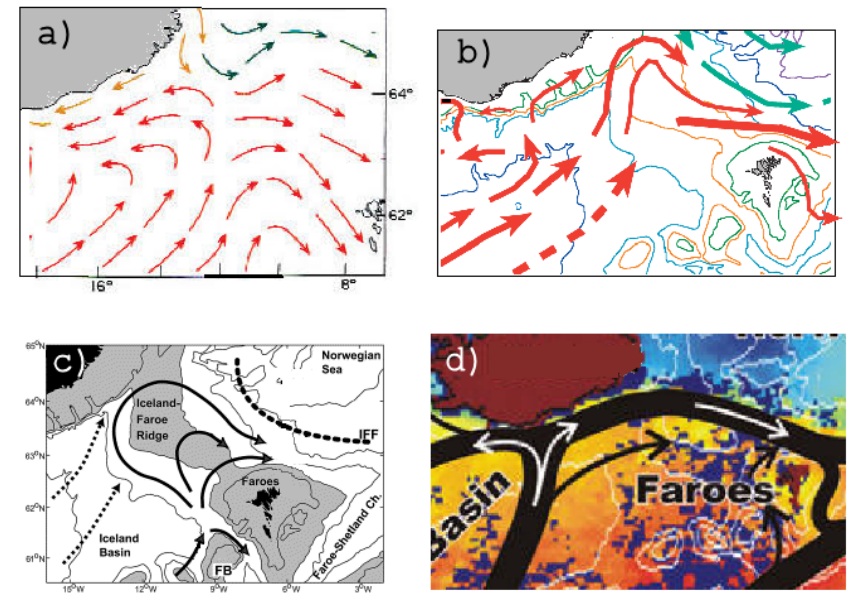

Fig. 19. Different interpretations of the Atlantic Water flow (red or black arrows) between Iceland and the Faroe Islands: (a) from Stefánsson and Ólafsson (1991), (b) from Valdimarsson and Malmberg (1999) based on drifter data, (c) the classical view of Atlantic Water pathways (unbroken arrows) and "alternative suggestions" (broken arrows) from Hansen et al. (2003), (d) the Atlantic Water pathways suggested by Orvik and Niiler (2002) based on drifter data. Modified after Stefánsson and Ólafsson (1991), Valdimarsson and Malmberg (1999), Orvik and Niiler (2002), and Hansen et al. (2003).

meaningful (below the ICC) and not along the entire resolution boundary.

The theory of secondary circulation related to Ekmanlayer dynamics (e.g. Holton, 1979; MacCready and Rhines, 1993) says that a system consisting of an along-shore density front, a coastal current in the Kelvin wave propagation direction and a counter-directed undercurrent implies upwelling within the density front. Such an upwelling could play an important role for the Icelandic ecosystem by carrying nutrients from the bottom layer up to the euphotic zone where the primary production is intensive (Ólafsson et al., 2008). This could be, in addition to the river-borne silicate, another cause of the higher phytoplankton productivity over the south-western shelf compared to that of the adjacent open sea as observed by Guðmundsson (1998).

Along with the ICC and ICUC, our focus was on the major currents in Icelandic waters, which mostly flow further offshore over the shelf or along the continental slope, their long-term mean spatial structures and the underlying forcing mechanisms. In order to analyse the forcing of the different currents, a set of numerical sensitivity experiments was carried out, whereby each experiment dealt with one specific physical forcing process.

The basis for these experiments was the assumption that the volume flux of a simulated current would collapse in a short period of time in the case that its relevant forcing process would have been deactivated within the model equations. Whereas this chain of thought is self-evident in the majority of the experiments, the situation becomes more com- plex in the case of experiment locRHO and gloRHO. Here, we are faced with the problem that, e.g. a wind-driven current in a stratified ocean will lead to horizontal density gradients which could be misinterpreted as forcing the current. However, deleting the horizontal density gradients from the model equations, like we did in experiments locRHO and gloRHO, would change the simulated vertical shear of the wind-driven current but it would not lead to a collapse of its volume transport. This collapse would happen only after the wind stress terms were deleted. When analysing the six sensitivity experiments we focussed on the vertically integrated flow, i.e. the volume transport, and thereby circumvent this problem of misinterpretation. It should be also noted that we ask for the immediate regional forcing, e.g. the pressure field resulting from sea level height gradients across the Arctic Front if the according geostrophic flow substantially corresponds to the analysed current and if a removal of this pressure field leads to a collapse of the current. However, we would like to stress here that the Arctic Front in turn is formed by structures like the basin-scale wind field, the meridional gradient of the ocean-atmosphere heat flux and the topography of the Greenland-Iceland-Scotland Ridge separating the different water masses.

One important result regarding the near-surface major currents is the general dominance of an eastward flow around Iceland caused by the different sea level height between the Atlantic Water to the south and the Arctic waters to the north. Two almost symmetric branches, the NIIC to the north and a current of similar strength herein called the South Icelandic Current (SIC) to the south carrying Atlantic Water along the north-western and south-eastern side of the island, respectively. Both currents are found to be forced by barotropic pressure gradients which form as a result of the Arctic Front's pressure field interacting with the topography of the Icelandic shelf (see Figs. 17b and 20). Though the local wind and the local baroclinic pressure gradient cause temporal variability of these currents, they are not their primary forcing. This independence of the coastal circulation on wind forcing is supported by the results of the numerical sensitivity experiments performed by Ólason (2006). Furthermore, our findings are in agreement with recent works on the forcing of the Faroe Current (FC) (Hansen et al., 2010; Richter et al., 2012; Sand $\varnothing$ et al., 2012). Herein, the meridional gradient of sea surface height across the Arctic Front, caused by the density gradient or even by the removal of dense water by the overflow (Hansen et al., 2010), is identified as the basic forcing of the FC. Therefore, the assumption of an analogous forcing of the SIC and NIIC appears to hold true.

The NIIC is simulated to bifurcate north of Denmark Strait into the iNIIC which flows eastward along the north Icelandic coast, and the oNIIC which follows the continental slope north of Iceland. Whereas the iNIIC can be traced downstream up to the north-east coast of Iceland, the oNIIC only reaches up to the Kolbeinsey Ridge. Here, parts of the current, which has further ramified into three sluggish branches, 

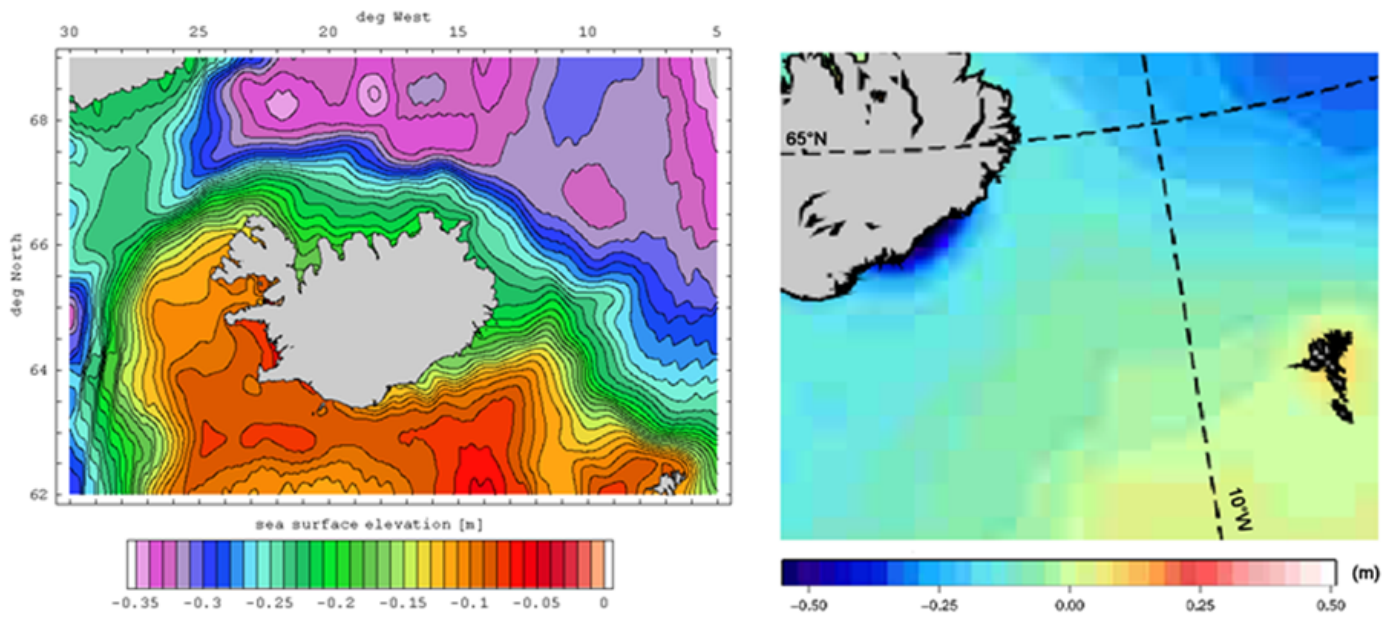

Fig. 20. Left: the simulated 1992-2006 mean sea surface elevation around Iceland. Right: the mean dynamic topography model of Hunegnaw et al. (2009) calculated from marine, airborne and satellite gravimetry, combined with satellite altimetry. Modified after Hunegnaw et al. (2009).

finally mixes into the Arctic waters of the East Icelandic Current (EIC) which flows southward along the eastern flank of the ridge. Note that, beside its temporal variability, the simulated shape of the oNIIC branching may also strongly depend on the vertical topography resolution which is, far away from the coast, only $160 \mathrm{~m}$.

The NIIC is the result of the signal of high dynamic sea level height south of Iceland which is led downstream along the west and north-west coasts. An analogous structure is found along the east and south-east coasts where the signal of low dynamic sea level height from north of Iceland is led southwards and upstream (Fig. 20). But how are these signals led? Is it possible that the Arctic Front density gradient off the east (west) coast forces a barotropic current up to $300 \mathrm{~km}$ further up-(down)-stream off the south (north) coast?

This problem was first examined by Csanady (1978) who discussed solutions of the stationary, linearised and depthaveraged equations of motion along an idealised coastal slope adjoining a deep sea area. His theory treats a coastal pressure and according flow signal which extends, from the region where an along slope sea surface gradient is imposed at the shelf break by a deep water dynamics, longshore in the direction of topographic wave propagation. Csanady denoted the structure as an "arrested topographic wave". Huthnance (1987) has analysed the corresponding flow adjustment on the shelf. He describes the evolution of a barotropic alongshore flow (even for baroclinic forcing). The distance and the direction over which this evolution takes place shows a close correspondence to the decay distance and direction of the lowest mode continental shelf wave which is in the order of $1000 \mathrm{~km}$. Huthnance points towards the clear decoupling of the coastal and the oceanic sea level in the case of an arrested topographic wave.
Over the south-eastern shelf the result of this effect is the SIC, simulated to flow with high intensity over the southern and south-eastern shelf to the east and north-east, respectively. Our simulation showed months with the SIC being stronger than the NIIC or EIC, and indicated that the SIC is a substantial source of the FC, and could even be interpreted as the FC preform.

We successfully reproduced the NIIC/SIC structure and showed its dependency on the topography and the density field with an idealised model setup: a circular island being placed on a zonal density front. This experiment resembles those of Hsieh and Gill (1984) addressing the Rossby adjustment problem (Rossby, 1937, 1938). Considering a meridional channel with a zonal density front Hsieh and Gill pointed to the existence of a northward western boundary current south of the density front and a northward eastern boundary current north of it, both being accompanied by deep counter-currents. They also discussed the application of their results to the hydrography of the Iceland-Faroe Ridge and, regarding their deep counter-currents, may have already shown the basic NIJ forcing mechanism.

However, are our model predictions of the SIC realistic? After all, a description of a specific eastward current over the southern and south-eastern Icelandic shelf, independent and separated from the North Atlantic Drift, does not exist within the classical view of Icelandic hydrography.

On the one hand, the near-surface flow field of the northern Iceland Basin is assumed to be predominantly topographically steered and cyclonic; perhaps a remnant of the circulation scheme of Nansen (1912), though his hypothesis referred to deeper layers. Here a broad $(>100 \mathrm{~km})$ and sluggish south-westward current of coastal and Atlantic Water is assumed along the south-east coast of Iceland (e.g., Stéfansson, 1962; see Fig. 19a). Furthermore, the source of the 
Atlantic Water of the FC is thought to stem mainly from the area north-west of the Faroe Bank, where the Atlantic Water flows north-westwards along the southern flank of the Iceland-Faroe Ridge until it crosses the ridge close to the Icelandic shelf to form the current (see Fig. 19c) (e.g., Hansen et al., 2003; Østerhus et al., 2005). However, Larsen et al. (2012) state that the Atlantic Water characteristics of the FC north of the Faroe Islands point towards a considerable admixture from south of Iceland, and Hansen et al. (2003), referring to Orvik and Niiler (2002), do mention the possibility of an "alternative", north-eastward path of the source waters (Fig. 19c).

Orvik and Niiler's (2002) dissentient path of the FC source waters was based on an analysis of surface drifter tracks south-west of Iceland (Fig. 19d). This is in agreement with our findings, regarding the bifurcation of the Atlantic Water flow into an eastward and a westward branch, with the eastward branch being the source path of the FC, although Orvik and Niiler made no reference to different dynamics of the eastward branch compared to the "wider, eddy structured" flow through the Iceland Basin south of Iceland. Several other empirical studies also lend support to this alternative view of the source path. For example, Hermann and Thomsen (1946), who published a circulation scheme based on drift bottle measurements, showed a clear north-eastward drift south-east of Iceland and in combination with the eastward flux along the Arctic Front, their scheme showed an anti-cyclonic structure of the near-surface circulation in the northern Iceland Basin. These pattern has subsequently been re-verified by modern drifter experiments (Perkins et al., 1998; Valdimarsson and Malmberg, 1999; Jakobsen et al., 2003) (Fig. 19b, d) partly also including CTD profiles and records of moored current meters from the area south-east of Iceland (Perkins et al., 1998). In accordance with our results, Perkins et al. (1998) have described an intense northeastward flow of Atlantic Water at the shelf break south-east of Iceland, being forced by the sea level height gradients of the Arctic Front.

Hence, the CODE simulation clearly supports a scheme of anti-cyclonic near surface circulation in the northern Iceland Basin. Though it shows a distinct increase of the SIC between section $13(0.7 \mathrm{~Sv})$ and section $12(1.7 \mathrm{~Sv})$, i.e., a swelling of the current by absorption of Atlantic Water from the south shortly before hitting the Iceland-Faroe Ridge. And though deeper portions of this water, being part of a deep, topographically steered slope current, may indeed stem from north-west of the Faroe Banks. In our simulation, the majority of the near-surface Atlantic Water east of Iceland is steered by the barotropic pressure field of the Arctic Front, which implies an eastward flow component over the IcelandFaroe Ridge (Fig. 6) and, furthermore, $33 \%$ of the FC water north of the Faroe Islands stem from the SIC west of $17^{\circ} \mathrm{W}$.

With the exception of the extensive field work of Perkins et al. (1998), which was however restricted to the shelf east of $14^{\circ} \mathrm{W}$, none of the drifter studies indicate a distinct SIC, i.e., an energetic dynamical structure over the south-east Icelandic shelf being independent from the North Atlantic Current further offshore. If we assume our simulation to be realistic, what could be the reason for the past invisibility of this current?

Our simulation shows very homogenous vertical current profiles of the SIC (Fig. 12), reflecting its forcing by a nearcoastal signal of low sea level height, independent from and not forming any local density gradient. This means that the SIC remains invisible when the dynamic method, based on CTD profiles, is applied. Furthermore, it is difficult to deduce a boundary current structure like the SIC from a limited number of surface drifter tracks. In addition, if we consider the fact that, in the Northern Hemisphere an eastward flow along a south coast forms an upwelling-favourable situation, we should assume a divergent near-surface flow field within the SIC. Hence, surface drifter would virtually be repelled from the current's core and most of the SIC would remain invisible when looking at the drifter tracks.

However, we found some observational evidence for the SIC when comparing drifter tracks (Valdimarsson and Malmberg, 1999) with the simulated flow field. Figure 5 shows the striking similarity between the observed and simulated eastward flow vectors south of Iceland. Note that Fig. 5 shows the longest red vector within Icelandic waters, i.e., the fastest observed drift vector from the used data set, which is located south-east of Iceland and points eastward.

Whereas the numerical simulation of Nilsen et al. (2003) already comprised a sparsely resolved SIC, the work of Hunegnaw et al. (2009) revealed further details. Their dynamic topography, calculated from marine, airborne and satellite gravimetry, combined with satellite altimetry, confirms our model results showing a strong SIC signal along major parts of the south-east coast and even a weak, probably just barely resolved, signal of eastward flow along the south coast (Fig. 20).

Hence, we assume that, in the absence of direct current measurements over the southern shelf, evidence for the SIC arose only after the emergence of high-resolution numerical ocean modelling (this study) or satellite altimetry (Hunegnaw et al., 2009). Therefore, it may be a new challenge for observational oceanography to verify the SIC postulated here.

Another current in Icelandic waters which has just recently been discovered (Jónsson and Valdimarsson, 2004) is the North Icelandic Jet (NIJ). Knowledge on the structure of the NIJ is still limited. However, our model results are in general consistency with the observations (Jónsson and Valdimarsson, 2004; Våge et al., 2011b), whereby the NIJ is predicted to flow from east of the Kolbeinsey Ridge as a deep undercurrent along the north Icelandic continental slope with a volume flux of 1.5 Sv when entering Denmark Strait. Anyhow, it has to be mentioned here that the NIJ volume flux east of the Kolbeinsey Ridge $(2 \mathrm{~Sv})$ and the NIJ core depth $(\approx 700 \mathrm{~m})$ are probably over-estimated by the model. An analysis of the 
sources and pathways of the Denmark Strait Overflow Water was beyond the scope of this paper. However, the simulated temperature and salinity values of the NIJ east of the Kolbeinsey Ridge ( $T=-0.46^{\circ} \mathrm{C}, S=34.889$ at section 10) are very close to those of the densest part of the Denmark Strait Overflow: $-0.48^{\circ} \mathrm{C}<T<-0.23^{\circ} \mathrm{C}, 34.90<S<34.91$ as observed by Våge et al. (2011b). Further downstream the simulated heat transfer from the overlaying NIIC into the NIJ is over-estimated, and the corresponding salt transfer may be under-estimated. This was probably caused by an insufficient vertical resolution $(80 \mathrm{~m})$ within the NIJ depth range, which could therefore not be effectively corrected by the CTD data assimilation. The consequence is a simulated NIJ that is too warm and too fresh when entering Denmark Strait $\left(T=0.43{ }^{\circ} \mathrm{C}, S=34.876\right.$ at section 4$)$. Thus, the simulated density over the sill is under-estimated and this may be the main reason of the under-estimated volume flux of the overflow in this study (simulated $1.33 \mathrm{~Sv}$ in contrast to $3.4 \mathrm{~Sv}$ observed by Jochumsen et al., 2012).

We found the NIJ to be forced by local baroclinic pressure gradients. These are caused between the warm Atlantic Water of the NIIC and cold Arctic waters adjacent in the north, i.e., by the Arctic Front. Like the SIC, the NIJ is associated with a secondary circulation which comprises an up-slope near-bottom flow. Convectively formed Arctic waters from deeper central parts of the Iceland Sea could be pumped up the North Icelandic continental slope and finally onto the sill of Denmark Strait. This would explain the NIJ's dominant role in providing the densest parts of the overflow (Vage et al., 2011b).

In terms of the temporal variability of the NIJ, the simulation indicates two primary characteristics. First, a trend of decreasing volume flux during the period 1992-2006. This decrease was most pronounced during the years 1999 and 2000 when the 13-months moving average of the westward volume flux north-west of Iceland (section 5) dropped from $1.5 \mathrm{~Sv}$ down to $0.6 \mathrm{~Sv}$. This may be related to the observed decrease of the Denmark Strait Overflow during the years 2000 to 2003 (Macrander et al., 2005). The trend of NIJ decrease is accompanied by a trend of NIIC increase. In accordance with Ólafsson (1999), Logemann and Harms (2006) we find the NIIC increase during the years 1999 to 2000 to be connected with the decrease of the southward wind stress over northern Denmark Strait (Fig. 13). The assumption of a reversed wind-induced effect on the NIJ north of Denmark Strait seems to be obvious. However, the lack of a clear wind stress trend over the entire simulation period points to other processes, perhaps linked to the weakening of the Subpolar Gyre circulation south of Iceland (Häkkinen and Rhines, 2004; Hátún et al., 2005), being responsible for the long term trends of both currents. Also, the trend of decreasing SIC could be connected to these basin-scale dynamics.

Secondly, both the NIJ and the NIIC show a volume flux maximum in 2003. An explanation for this could be an increased density contrast of the Arctic Front, caused by an in- creased NIIC forming a stronger NIJ forcing. Further studies should examine this mechanism and its impact on the variability of the Denmark Strait overflow as well as the formation processes of the NIJ water, which may become a key issue for our understanding of the Atlantic meridional overturning circulation.

In conclusion, our numerical ocean model CODE, established on the basis of the differential equations of ocean physics together with hydrographic measurements, has given us a number of new insights into the circulation of Icelandic waters. We hope it could contribute to a further clarification of certain objects of the regional oceanography - the structure of the ICC, the primary forcing of the NIIC and the circulation patterns south-east of Iceland. We have extracted several detailed and previously unknown structures (e.g., the SIC, the ICUC or the NIIC bifurcations) and proposed explanations of the resolved currents' dynamics. Of course, these postulates require observational verification and an expansion of the simulation's temporal range. This would provide further insights on the relevance of our results to the Icelandic marine ecosystem, the local circulation's role within the Atlantic meridional overturning circulation and its behaviour in a changing marine climate.

Acknowledgements. The authors would like to thank Bergur Einarsson, Icelandic Meteorological Office, for providing the WaSiM hydrological model output. Thanks also to Halldór Björnsson, Icelandic Meteorological Office, Heidi Pardoe, and Jed Macdonald, University of Iceland, for commenting on the paper. We further acknowledge the input of the three anonymous reviewers who helped us to correct, clarify and improve numerous aspects. This work has been supported by the Icelandic Research Fund, RANNÍS, Grant No. 110655-0611, Marsýn-Upplýsingakerfi fyrir safarendur i Norður Atlantshafi, the Icelandic Technology Developmental Fund, the University of Iceland Research Fund, the Rector of the University of Iceland and the Ministry of Fisheries Special Project Fund.

Edited by: A. Sterl

\section{References}

Apel, J. R.: Principles of Ocean Physics, Academic Press Limited, London, 209-219, 1987.

Astpórsson, O. S., Gislason, A., and Jónsson, S.: Climate variability and the Icelandic marine ecosystem, Deep-Sea Res. II, 54, 24562477, 2007.

Bjerknes, V.: On the dynamics of the circular vortex with application to the atmosphere and atmospheric vortex and wave motions, Geofysiske Publikationer, Kristiania, 2, 90 pp., 1921.

Bloom, S. C., Takacs, L. L., da Silva, A. M., and Ledvina, D.: Data Assimilation Using Incremental Analysis Updates, Mon. Weather Rev., 124, 1256-1271, 1996.

Blumberg, A. F. and Mellor, G. L.: A description of a three-dimensional coastal ocean circulation model, in: Three- 
Dimensional Coastal Ocean Models, edited by: Heaps, N. S., American Geophysical Union, Washington, DC, 1-16, 1987.

Csanady, G. T.: The arrested topographic wave, J. Phys. Oceanogr., 8, 47-62, 1978

Chapman, D. C. and Lentz, S. J.: Trapping of a Coastal Density Front by the Bottom Boundary Layer, J. Phys. Oceanogr., 24, 1464-1479, 1994.

Eggertsson, O.: Origin of driftwood on the coasts of Iceland, a dendrochronological study, Jökull, 43, 1-16, 1994.

Einarsson B. and Jónsson, S.: Improving groundwater representation and the parameterization of glacial melting and evapotranspiration in applications of the WaSiM hydrological model within Iceland, Report 2010-017, Icelandic Meteorological Office, 29 pp., 2010.

Fofonoff, N. P. and Millard, R. C.: Algorithms for computation of fundamental properties of sea water, UNESCO Technical Papers in Marine Science, 44 pp., 1983.

Gill, A. E.: Atmosphere-Ocean Dynamics, International Geophysics Series, Academic Press, London, 22-38, 1982.

Grell, G. A., Duhia, J., and Stauffer, D. R.: A description of the fifth generation Penn. State/NCAR Mesoscale Model (MM5), NCAR Tech. Note NCAR/TN398+STR, 138 pp., 1994.

Griffies, S., Boning, C., Bryan, F., Chassignet, E., Gerdes, R., Hasumi, H., Hirst, A., Treguier, A.-M., and Webb, D.: Developments in ocean climate modelling, Ocean Modelling, 2, 123-192, 2000.

Griffies, S. M., Harrison, M. J., Pacanowski, R. C., and Rosati, A.: A technical guide to MOM4 - GFDL ocean group technical report No. 5., NOAA/Geophysical Fluid Dynamics Laboratory, 2004.

Guðmundsson, K.: Long-term variation in phytoplankton productivity during spring in Icelandic waters, ICES J. Mar. Sci., 55, 635-643, 1998

Häkkinen, S. and Rhines, P. B.: Decline of Subpolar North Atlantic Circulation During the 1990s, Science, 304, 555-559, 2004.

Halldórsdóttir, S.: Áhrif afrennslis og tímaaupplausnar vindasviðs á reiknaða yfirborðsstrauma við Ísland, Master thesis, Department of Physics, University of Iceland, 91 pp., 2006.

Hansen, B. and Meincke, J.: Eddies and meanders in the IcelandFaroe Ridge area. Deep-Sea Res., 26A, 162-169, 1979.

Hansen, B., Østerhus, S., Hátún, H., Kristiansen, R., and Larsen, K. M. H.: The Iceland-Faroe inflow of Atlantic water to the Nordic seas, Prog. Oceanogr., 59, 443-474, 2003.

Hansen, B., Hátún, H., Kristiansen, R., Olsen, S. M., and Østerhus, S.: Stability and forcing of the Iceland - Faroe inflow of water, heat, and salt to the Arctic, Ocean Sci., 6, 1013-1026, 2010, http://www.ocean-sci.net/6/1013/2010/.

Hátún, H., Sandø, A. B., Drange, H., Hansen, B., Valdimarsson, H.: Influence of the Atlantic Subpolar Gyre on the Thermohaline Circulation, Science, 309, 1841-1844, 2005.

Hermann, F. and Thomsen, H.: Drift bottle experiments in the northern North Atlantic, Medd. Komm. Danm. Fisk. Havunders., serie Hydrografi, Bind III, nr. 4, 87 pp., 1946.

Hibler, W. D.: A Dynamic Thermodynamic Sea Ice Model, J. Phys. Oceanogr., 9, 815-846, 1979.

Hodges, K. I., Lee, R. W., and Bengtsson, L.: A Comparison of Extratropical Cyclones in Recent Reanalyses ERA-Interim, NASA MERRA, NCEP CFSR, and JRA-25, J. Climate, 24, 4888-4906, doi:10.1175/2011JCLI4097.1, 2011.
Holton, J. R.: An Introduction to Dynamic Meteorology, 3 Edn., Academic Press, London, 133-140, 1979.

Hsieh, W. W. and Gill, A. E.: The Rossby Adjustment Problem in a Rotating, Stratified Channel, with and without Topography, J. Phys. Oceanogr., 14, 424-437, 1984.

Hunegnaw, A., Siegismund, F., Hipkin, R., and Mork, K. A.: Absolute flow field estimation for the Nordic seas from combined gravimetric, altimetric, and in situ data, J. Geophys. Res., Vol. 114, C02022, doi:10.1029/2008JC004797, 2009.

Huthnance, J. M.: Along-shelf evolution and sea levels across the continental slope, Cont. Shelf Res., 7/8, 957-974, 1987.

ICES: VEINS - Variability of Exchanges in the Northern Seas, EC - MAST III Project, 1997-2000, International Council for the Exploration of the Sea, CD-ROM, 2000.

Jakobsen, P. K, Ribergaard, M. H., Quadfasel, D., Schmith, T., and Hughes, C. W.: Near-surface circulation in the northern North Atlantic as inferred from Lagrangian drifters: Variability from the mesoscale to interannual, J. Geophys. Res., 108, 3251, doi:10.1029/2002JC001554, 2003.

Jochumsen, K., Quadfasel, D., Valdimarsson, H., and Jónsson, S.: Variability of the Denmark Strait overflow: Moored time series from 1996-2011, J. Geophys. Res., 117, C12003, doi:10.1029/2012JC008244, 2012.

Jónsson, S.: Volume flux and fresh water transport associated with the East Icelandic Current, Prog. Oceanogr., 73, 231-241, 2007.

Jónsson, S. and Valdimarsson, H.: A new path for the Denmark Strait overflow water from the Iceland Sea to Denmark Strait, Geophys. Res. Lett., 31, L03305, doi:10.1029/2003GL019214, 2004.

Jónsson, S. and Valdimarsson, H.: The flow of Atlantic water to the North Icelandic Shelf and its relation to the drift of cod larvae, ICES J. Mar. Sci., 62, 1350-1359, 2005.

Jónsson, S. and Valdimarsson, H.: Water mass transport variability to the North Icelandic shelf, 1994-2010, ICES J. Mar. Sci., 69, 809-815. doi:10.1093/icesjms/fss024, 2012.

Kalnay, E., Kanamitsu, M., Kistler, R., Collins, W., Deaven, D., Gandin, L., Iredell, M., Saha, S., White, G., Woollen, J., Zhu, Y., Chelliah, M., Ebisuzaki, W., Higgins, W., Janowiak, J., Mo, K.C., Ropelewski, C., Wang, J., Leetmaa, A., Reynolds, R., Jenne, R., and Joseph, D.: The NCEP/NCAR 40-year reanalysis project, B. Am. Meteorol. Soc., 77, 437-471, 1996.

Khokhlov, A.M.: Fully threaded tree algorithms for adaptive refinement fluid dynamics simulations, J. Comp. Phys., 143, 2, 519543, 1998.

Kochergin, V.P.: Three-dimensional prognostic models, in: Threedimensional coastal ocean models, edited by: Heaps, N. S., Coast. Est. Sci., 4, 201-208, 1987.

Kristmannsson, S. S.: Flow of Atlantic Water into the northern Icelandic shelf area, 1985-1989, ICES Cooperative Research Report, 225, 124-135, 1998.

Larsen, K.M.H., Hátun, H., Hansen, B., and Kristiansen, R.: Atlantic water in the Faroe area: sources and variability, ICES J. Mar. Sci., 69, 802-808, doi:10.1093/icesjms/fss028, 2012.

Li, L., Wang, H., and Sun, R.: Seasonal change of steric sea level in the GIN seas, Journal of Ocean University of China, Vol. 10, Issue 1, 16-22, doi:10.1007/s11802-011-1762-0, 2011.

Logemann, K. and Harms, I.: High resolution modelling of the North Icelandic Irminger Current (NIIC), Ocean Sci., 2, 291- 
304, 2006,

http://www.ocean-sci.net/2/291/2006/.

Logemann, K., Ólafsson, J., and Marteinsdóttir, G.: The ocean model CODE and its application to Icelandic waters, MARICE E-report MER-10-2010, University of Iceland, 93 pp., http:// www.marice.is/ereports/MER-10-2010.pdf, 2010.

Logemann, K., Ólafsson, J., and Marteinsdóttir, G.: Modelling the hydrography of Icelandic waters from 1992 to 2006, MARICE E-report MER-13-2012, 221 pp., www.marice.is/ ereports/MER-13-2012.pdf, 2012.

MacCready, P. and Rhines, P. B.: Slippery Bottom Boundary Layers on a Slope, J. Phys. Oceanogr., 23, 5-22, 1993.

Macrander, A., U. Send, H. Valdimarsson, S. Jónsson, and R. H. Käse: Interannual changes in the overflow from the Nordic seas into the Atlantic Ocean through Denmark Strait, Geophys. Res. Lett., 32, L06606, doi:10.1029/2004GL021463, 2005.

Malmberg, S. A. and Kristmannsson, S. S.: Hydrographic conditions in Icelandic waters, 1980-1989. ICES Mar. Sci. Symp., 195, 76-92, 1992.

Marteinsdóttir, G. and Astpórsson, O. S.: Iceland, in: Spawning and Life History Information for North Atlantic CodStocks, ICES Cooperative Research Report, 274, edited by: Brander, K., ICES, Copenhagen, 56-61, 2005.

Mesinger, F., Arakawa, A.: Numerical methods used in atmospheric models, Volume I, GARP Publication Series, 17, 64 pp., 1976.

Millero, F. J., Chen, C.-T, Bradshaw, A., and Schleicher, K.: A new high pressure equation of state for seawater, Deep-Sea Res., 27, 255-264, 1980.

Mooney, P. A., Mulligan, F. J., and Fealy, R.: Comparison of ERA40, ERA-Interim and NCEP/NCAR reanalysis data with observed surface air temperatures over Ireland, Int. J. Climatol., 31, 4, 545-557, doi:10.1002/joc.2098, 2011.

Mortensen, J.: Satellite altimetry and circulation in the Denmark Strait and adjacent seas, Marine Research Institute, Report no. 108, 84 pp., 2004.

Nansen, F.: Das Bodenwasser und die Abkühlung des Meeres, Internationale Revue der Gesamten Hydrobiologie und Hydrographie, $5,1-42,1912$.

Nilsen, J. E. Ø., Gao, Y., Drange, H., Furevik, T., and Bentsen, M.: Simulated North Atlantic - Nordic Seas water mass exchanges in an isopycnic coordinate OGCM, Geophys. Res. Letters, 30, 1536, doi:10.1029/2002GL016597, 2003.

Nilsen, J. E.Ø., Hatún, H., Mork, K. A., and Valdimarsson, H.: The NISE Data Collection, Report published on CD-ROM, 20 pp., 2006.

Ólafsson, J.: Recruitment of Icelandic haddock and cod in relation to variability in the physical environment. ICES, C.M.1985/G:59, 17 pp., 1985.

Ólafsson, J.: Connections between oceanic conditions of N-Iceland, Lake Mývatn temperature, regional wind direction variability and the North Atlantic Oscillation, Rit Fiskideildar, J. Mar. Res. Inst. Reykjavik, 16, 41-57, 1999.

Ólafsson, J., Danielsen, M., Ólafsdóttir, S. R., and Briem, J.: Ferskvatnsáhrif í sjó við Norðausturland að vorlagi - Unnið fyrir Orkustofnun og Landsvirkjun, Hafrannsóknastofnunin, fjölrit nr. 86, 45 pp., 2002.

Ólafsson, J., Ólafsdóttir, S. R., and Briem, J.: Vatnsföll og vistkerfi strandsjávar, Náttúrufræðingurinn, 76, 95-108, 2008.
Ólason, E.Ö.: Oceanic circulation and variability around Iceland, A numerical study, Master thesis, Department of Physics, University of Iceland, 226 pp., 2006.

Orvik, K. A. and Niiler, P.: Major pathways of Atlantic water in the northern North Atlantic and Nordic Seas toward Arctic, Geophys. Res. Lett., 29, 1896, doi:10.1029/2002GL015002, 2002.

Orvik, K. A., Skagseth, Ø., and Mork, M.: Atlantic inflow to the Nordic Seas: current structure and volume fluxes from moored current meters, VM-ADCP and SeaSoar-CTD observations, 1995-1999, Deep-Sea Res., I, 48, 937-957, 2001.

Østerhus, S., Turrell, W. R., Jónsson, S., and Hansen, B.: Measured volume, heat, and salt fluxes from the Atlantic to the Arctic Mediterranean, Geophys. Res. Lett., Vol. 32, L07603, doi:10.1029/2004GL022188, 2005.

Pedlosky, J.: Geophysical Fluid Dynamics, Springer-Verlag, New York, 710 pp., 1987.

Perkins, H., Hopkins, T. S., Malmberg, S.-A., Poulain, P.-M., and Warn-Varnas, A.: Oceanographic conditions east of Iceland, J. Geophys. Res., 103, 21531-21542, 1998.

Pickart, R. S.: Bottom Boundary Layer Structure and Detachment in the Shelfbreak Jet in the Middle Atlantic Bight, J. Phys. Oceanogr., 30, 2668-2686, 2000

Pohlmann, T.: Predicting the thermocline in a circulation model of the North Sea - Part I: model description, calibration and verification, Cont. Shelf Res., 16, 131-146, 1996.

Popinet, S. and Rickard, G.: A tree-based solver for adaptive ocean modelling, Ocean Modelling, 16, 224-249, 2007.

Rasmussen, E. B.: A finite difference scheme for three-dimensional modelling of fluid dynamics, XXIV IAHR Congress, Madrid, 913 Sept. 1991, C339-C348, 1991.

Richter, K., Segtnan, O. H., and Furevik, T.: Variability of the Atlantic inflow to the Nordic Seas and its causes inferred from observations of sea surface height, J. Geophys. Res., 117, C04004, doi:10.1029/2011JC007719, 2012.

Rögnvaldsson, Ó., Jónsdóttir, J. F., and Ólafsson, H.: Numerical simulations of precipitation in the complex terrain of Iceland Comparison with glaciological and hydrological data, Meteorologische Zeitschrift, 16, 071-085, 2007.

Rossby, C. G.: On the mutual adjustment of pressure and velocity distributions in certain simple current systems: I, J. Mar. Res., 1, 15-28, 1937.

Rossby, C. G.: On the mutual adjustment of pressure and velocity distributions in certain simple current systems: II, J. Mar. Res., 2, 239-263, 1938.

Sand $\varnothing$, A. B., Nilsen, J. E.Ø., Eldevik, T., and Bentsen, M.: Mechanisms for variable North Atlantic - Nordic seas exchanges, J. Geophys. Res., 117, C12006, doi:10.1029/2012JC008177, 2012.

Sarafanov, A., Falina, A., Mercier, H., Sokov, A., Lherminier, P., Gourcuff, C., Gladyshev, S., Gaillard, F., Daniault, N.: Mean fulldepth summer circulation and transports at the northern periphery of the Atlantic Ocean in the 2000s, J. Geophys. Res., 117, C01014, doi:10.1029/2011JC007572, 2012

Schulla, J. and Jasper, K.: Model Description WaSiM-ETH. Technical report, ETH Zürich, 181 pp., 2007.

Smagorinsky J.: General Circulation Experiments with the Primitive Equations, I. The Basic Experiment. Mon. Weather Rev., 91, 99-106. 1963. 
Steele, M., Morley, R., and Ermold, W.: PHC: A global ocean hydrography with a high quality Arctic Ocean, J. Climate 14, 2079 2087, 2001.

Stefánsson, U.: North Icelandic waters, Rit Fiskideildar, 3, 269 pp., 1962.

Stefánsson, U. and Guðmundsson, G.: The Freshwater Regime of Faxaflói, Southwest Iceland, and its Relationship to Meteorological Variables, Estuar. Coast. Mar. Sci., 6, 535-551, 1978.

Stefánsson, U. and Ólafsson, J.: Nutrients and fertility of Iclandic waters, Rit Fiskideildar, 7, 1-56, 1991.

Swift, J. H.: The Arctic Waters, in: Hurdle, B. G., The Nordic Seas, Springer, New York, 129-153, 1986.

Tilinina, N., Gulev, S. K., Rudeva, I., and Koltermann, P.: Comparing Cyclone Life Cycle Characteristics and Their Interannual Variability in Different Reanalyses, J. Climate, 26, 6419-6438, doi:10.1175/JCLI-D-12-00777.1, 2013.

Tómasson, G. G. and Eliasson, J.: Numerical Modelling of Tides Around Iceland. In Computer Modelling of Seas and Coastal Regions II, edited by C.A. Brebbia, L. Traversoni, and L.C. Wrobel, Computational Mechanics Publications, Southampton, U.K. From the Second International Conference on Computer Modelling of Seas and Coastal Regions (COASTAL '95), 1995.

Tómasson, G .G. and Káradóttir, Ó. R.: A two dimensional numerical model of astronomical tide and storm surge in the North Atlantic Ocean. In: Viggosson, G. (ed): Second International Coastal Symposium in Iceland, Höfn, Hornafjörður, 5-8 June 2005, Icelandic Maritime Administration, Abstract volume, 266-267, 2005.

Våge, K., Pickart, R. S., Sarafanov, A., Knutsen, Ø., Mercier, H., Lherminier, P., Bersch, M., van Aken, H. M., Meincke, J., Quadfasel, D., and Bacon, S.: The Irminger Gyre: Circulation, convection, and interannual variability, Deep-Sea Res. I, 58, 590-614, doi:10.1016/j.dsr.2011.03.001, 2011a.
Våge, K., Pickart, R. S., Spall, M.A., Valdimarsson, H., Jónsson, S., Torres, D. J., Østerhus, S., and Eldevik, T.: Significant role of the North Icelandic Jet in the formation of Denmark Strait overflow water, Nat. Geosci., 4, 723-727, 2011 b.

Våge, K., Pickart, R. S., Spall, M. A., Moore, G. W. K., Valdimarsson, H., Torres, D. J., Erofeeva, S. Y., and Nilsen, J. E. Ø.: Revised circulation scheme north of the Denmark Strait, Deep-Sea Res. I, 79, 20-39, doi:10.1016/j.dsr.2013.05.00, 2013.

Valdimarsson, H.: Circulation in Icelandic waters from satellite tracked drifters, altimetry and ATSR. Cand. scient. thesis, Niels Bohr Institute, University of Copenhagen, 65 pp., 1998.

Valdimarsson, H. and Malmberg, S.-A.: Near-surface circulation in Icelandic waters derived from satellite tracked drifters, Rit Fiskideildar., J. Mar. Res. Inst. Reykjavik, 16, 23-39, 1999.

van Leer, B.: Towards the Ultimate Conservative Difference Scheme, V: A Second Order Sequel to Godunov's Method, J. Comput. Phys. 32, 101-136, 1979.

Vilhjálmsson, H.: Climatic variations and some examples of their effects on the marine ecology of Icelandic and Greenland waters, in particular during the present century, Rit Fiskideildar, 13, 929, 1997.

Wunsch C. and Heimbach, P.: Practical global state estimation, Physica D, 230, 197-208, doi:10.1016/J.PHYSD.2006.09.040, 2007.

Pórðardóttir, P.: Timing and duration of spring blooming south and southwest of Iceland, in: The Role of Freshwater Outflow in Coastal Marine Ecosystems, edited by: Skreslet, S., NATO ASI Series, Vol. G7, Springer, Berlin, 345-360, 1986. 